Nevada

Environmental

Restoration

Project

\title{
Subsurface Completion Report for Amchitka Underground Nuclear Test Sites: Long Shot, Milrow, and Cannikin
}

Revision No.: 1

September 2006

Approved for public release; further dissemination unlimited.

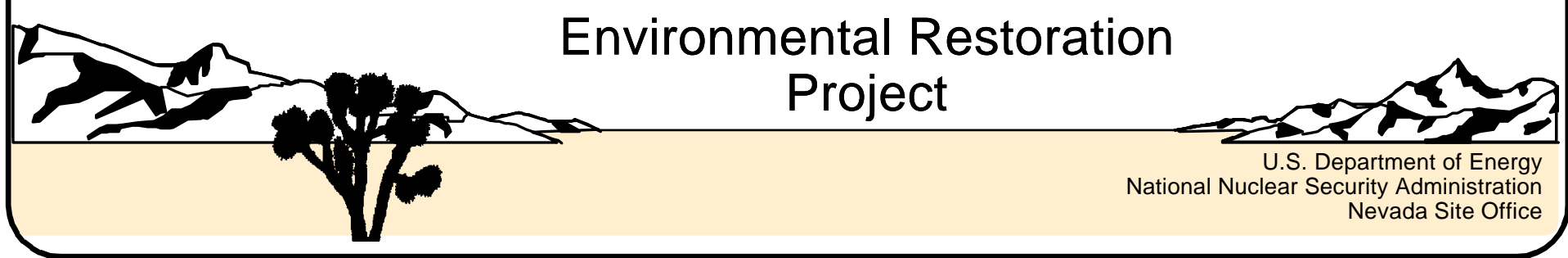


Available for public sale, in paper, from:

U.S. Department of Commerce

National Technical Information Service

5285 Port Royal Road

Springfield, VA 22161

Phone: 800.553.6847

Fax: 703.605.6900

Email: orders@ntis.gov

Online ordering: http://www.ntis.gov/ordering.htm

Available electronically at http://www.osti.gov/bridge

Available for a processing fee to U.S. Department of Energy and its contractors, in paper, from:

\section{U.S. Department of Energy}

Office of Scientific and Technical Information

P.O. Box 62

Oak Ridge, TN 37831-0062

Phone: 865.576.8401

Fax: 865.576.5728

Email: reports@adonis.osti.gov

Reference herein to any specific commercial product, process, or service by trade name, trademark, manufacturer, or otherwise, does not necessarily constitute or imply its endorsement, recommendation, or favoring by the United States Government or any agency thereof or its contractors or subcontractors. 


\title{
SUBSURFACE COMPLETION REPORT FOR AMCHITKA UNDERGROUND NUCLEAR TEST SITES: LONG SHOT, MILROW, AND CANNIKIN
}

\author{
U.S. Department of Energy \\ National Nuclear Security Administration \\ Nevada Site Office \\ Las Vegas, Nevada
}

Revision No.: 1

September 2006 
SUBSURFACE COMPLETION REPORT FOR

AMCHITKA UNDERGROUND NUCLEAR TEST SITES:

LONG SHOT, MILROW, AND CANNIKIN

Approved by: APPROVED SIGNATURE

Date: 9/12/2006

John B. Jones

Offsites Federal Sub-Project Director

Environmental Restoration Project

Approved by: APPROVED SIGNATURE

Date: $9 / 12 / 2006$

Janet Appenzeller-Wing

Federal Project Director

Environmental Restoration Project 


\section{Table of Contents}

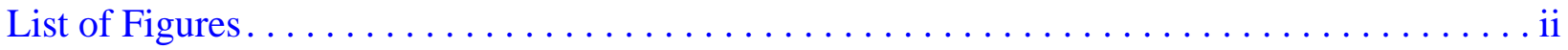

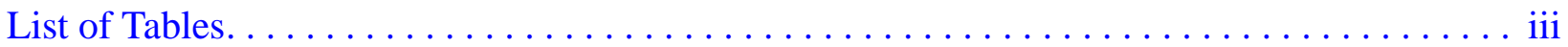

List of Acronyms and Abbreviations $\ldots \ldots \ldots \ldots \ldots \ldots \ldots \ldots \ldots \ldots \ldots \ldots \ldots \ldots \ldots$

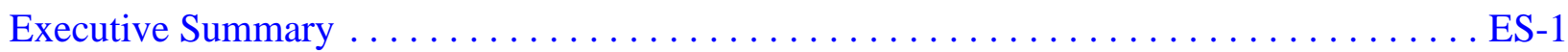

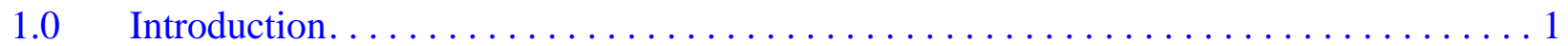

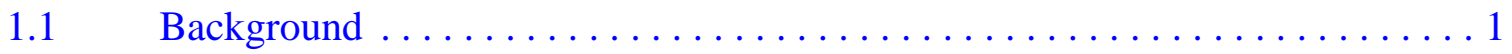

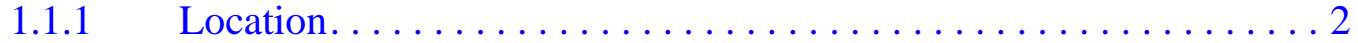

$1.1 .2 \quad$ Historic Uses . . . . . . . . . . . . . . . . . . . 2

1.1.3 Current and Future Use . . . . . . . . . . . . . . . . 13

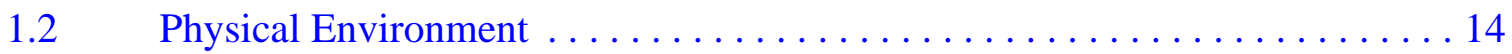

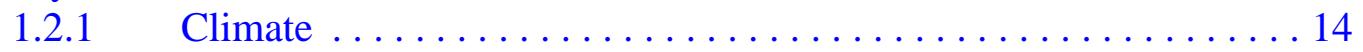

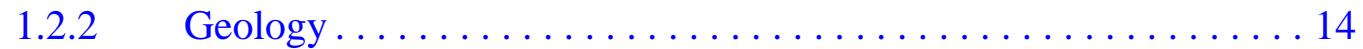

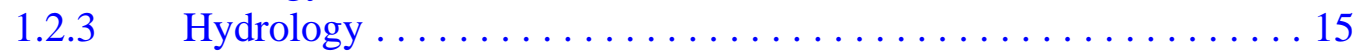

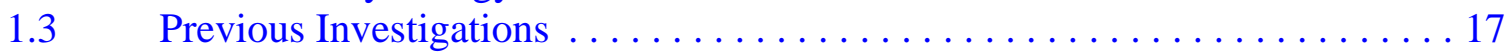

1.3.1 The Environment of Amchitka Island (Merritt and Fuller, 1977). . 17

1.3.2 Tritium Sampling . . . . . . . . . . . . . . . . . 20

1.3.3 Investigation of Radionuclides in Amchitka Island,

Alaska Ecosystems (Dasher et al., 2004) . . . . . . . . . . . . . 21

1.3.4 Long-Term Hydrologic Monitoring Program . . . . . . . . . . . . . . . 22

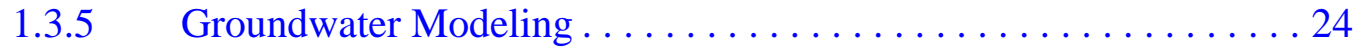

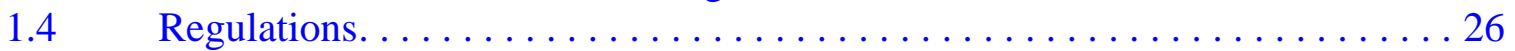

2.0 Site Completion Justification $\ldots \ldots \ldots \ldots \ldots \ldots \ldots \ldots \ldots \ldots \ldots \ldots \ldots \ldots \ldots \ldots$

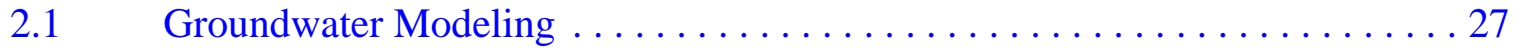

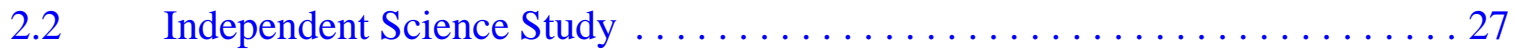

Completion Recommendation and Strategy . . . . . . . . . . . . . . 31

$3.1 \quad$ Recommendations . . . . . . . . . . . . . . . . . . . 31

3.1.1 Recommended Alternative .................... 31

$3.2 \quad$ Institutional Controls . . . . . . . . . . . . . . . . . . . . . 31

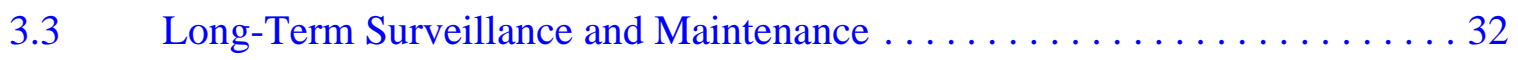

3.4 Governing Documents . . . . . . . . . . . . . . . . . 33

3.4.1 Long-Term Surveillance and Maintenance Plan Requirements . . . . 33

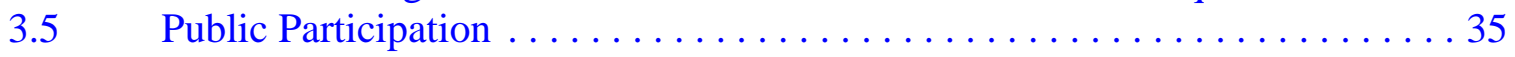

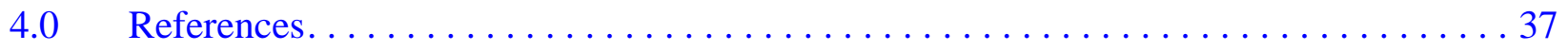




\section{List of Figures}

Number

Title

Page

1-1 Aleutian Islands and Amchitka Island $\ldots \ldots \ldots \ldots \ldots \ldots \ldots \ldots \ldots$

1-2 Amchitka Island Showing Drilling and Test Sites $\ldots \ldots \ldots \ldots \ldots \ldots \ldots$

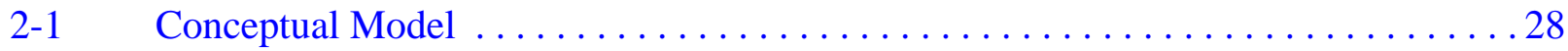




\section{List of Tables}

Number

$1-1$

1-2 Well Abandonment Details

1-3 Groundwater Wells and Sampling Depths.
Page

Title

\section{6} 8

23 


\section{List of Acronyms and Abbreviations}

\begin{tabular}{|c|c|}
\hline ACCA & Aleut Culture and Communication Area \\
\hline AEC & U.S. Atomic Energy Commission \\
\hline AMNWR & Alaska Maritime National Wildlife Refuge \\
\hline APIAI & Aleutian/Pribilof Islands Association, Inc \\
\hline bgs & Below ground surface \\
\hline CERCLA & Comprehensive Environmental Response, Compensation, and Liability Act \\
\hline $\mathrm{cm} /$ year & Centimeters per year \\
\hline CRESP & Consortium for Risk Evaluation with Stakeholder Participation \\
\hline Cs & Cesium \\
\hline DoD & U.S. Department of Defense \\
\hline DOE & U.S. Department of Energy \\
\hline DOI & U.S. Department of the Interior \\
\hline EIS & Environmental Impact Statement \\
\hline EM & Environmental Management \\
\hline EPA & U.S. Environmental Protection Agency \\
\hline${ }^{\circ} \mathrm{F}$ & Degrees Fahrenheit \\
\hline $\mathrm{ft}$ & Foot \\
\hline $\mathrm{ft}^{3}$ & Cubic foot \\
\hline ft bgs & Feet below ground surface \\
\hline GZ & Ground zero \\
\hline I.D. & Inside diameter \\
\hline in. & Inch \\
\hline $\mathrm{km}$ & Kilometer \\
\hline kt & Kiloton \\
\hline $\mathrm{LM}$ & Legacy Management \\
\hline LTSMP & Long-Term Surveillance and Maintenance Plan \\
\hline
\end{tabular}




\section{List of Acronyms and Abbreviations (Continued)}

$\begin{array}{ll}\text { MDA } & \text { Minimum detection activity } \\ \text { mi } & \text { Mile } \\ \text { mi }^{2} & \text { Square mile } \\ \text { MOA } & \text { Memorandum of Agreement } \\ \text { mph } & \text { Miles per hour } \\ \text { mrem/yr } & \text { Millirem per year } \\ \text { NNSA/NSO } & \text { U.S. Department of Energy, National Nuclear Security Administration Nevada } \\ \text { NTS } & \text { Site Office } \\ \text { O.D. } & \text { Nevada Test Site } \\ \text { ONR } & \text { Outside diameter } \\ \text { pCi/L } & \text { Office of Naval Research } \\ \text { Pu } & \text { Picocuries per liter } \\ \text { SGZ } & \text { Plutonium } \\ \text { Sr } & \text { Surface ground zero } \\ \text { USFWS } & \text { Strontium } \\ \text { USGS } & \text { U.S. Fish and Wildlife Service } \\ & \end{array}$




\section{Executive Summary}

Three underground nuclear tests were conducted on Amchitka Island, Alaska, in 1965, 1969, and 1971. The effects of the Long Shot, Milrow, and Cannikin tests on the environment were extensively investigated during and following the detonations, and the area continues to be monitored today.

This report is intended to document the basis for the Amchitka Underground Nuclear Test Sites: Long Shot, Milrow, and Cannikin (hereafter referred to as "Amchitka Site”) subsurface completion recommendation of No Further Remedial Action Planned with Long-Term Surveillance and Maintenance, and define the long-term surveillance and maintenance strategy for the subsurface.

A number of factors were considered in evaluating and selecting this recommendation for the Amchitka Site. Historical studies and monitoring data, ongoing monitoring data, the results of groundwater modeling, and the results of an independent stakeholder-guided scientific investigation were also considered in deciding the completion action.

Water sampling during and following the testing showed no indication that radionuclides were released to the near surface, or marine environment with the exception of tritium, krypton-85, and iodine-131 found in the immediate vicinity of Long Shot surface ground zero. One year after Long Shot, only tritium was detectable (Merritt and Fuller, 1977). These tritium levels, which were routinely monitored and have continued to decline since the test, are above background levels but well below the current safe drinking water standard. There are currently no feasible means to contain or remove radionuclides in or around the test cavities beneath the sites.

Surface remediation was conducted in 2001. Eleven drilling mud pits associated with the Long Shot, Milrow and Cannikin sites were remediated. Ten pits were remediated by stabilizing the contaminants and constructing an impermeable cap over each pit. One pit was remediated by removing all of the contaminated mud for consolidation in another pit. In addition to the mud pits, the hot mix plant was also remediated.

Ongoing monitoring data does not indicate that radionuclides are currently seeping into the marine environment. Additionally, the groundwater modeling results indicate no seepage is expected for tens 
to thousands of years. If seepage does occur in the future, however, the rich, diverse ecosystems around the island could be at risk, as well as people eating foods from the area.

An independent science study was conducted by the Consortium for Risk Evaluation with Stakeholder Participation (CRESP) in accordance with the Amchitka Independent Science Plan (2003). The study report was published on August 1, 2005. The CRESP study states "our geophysical and biological analyses did not find evidence of risk from radionuclides from the consumption of marine foods, nor indication of any current radionuclide contaminated migration into the marine environment from the Amchitka test shots.” The study also found evidence supporting the groundwater modeling conclusions of very slow contaminant transport (CRESP, 2005).

While no further action is recommended for the subsurface of the Amchitka Site, long-term stewardship of Amchitka Island will be instituted and will continue into the future. This will include institutional controls management and enforcement, post-completion monitoring, performance of five-year reviews, public participation, and records management. Long-term stewardship will be the responsibility of the U.S. Department of Energy Office of Legacy Management.

The Department of Energy is recommending completion of the investigation phase of the Amchitka Sites. The recommended remedy for the Amchitka Site is No Further Action with Long-Term Monitoring and Surveillance.

The future long-term stewardship actions will be governed by a Long-Term Surveillance and Maintenance Plan. This Plan is currently being developed with input from the State, landowner, and other interested or affected stakeholders. 


\subsection{Introduction}

Because of the environmental liability created by past nuclear testing activities at Amchitka Island, Alaska, the U.S. Department of Energy (DOE), National Nuclear Security Administration Nevada Site Office (NNSA/NSO) must demonstrate due process and due diligence in its cleanup process. Therefore, proper documentation of site cleanup, particularly its completion, is essential in demonstrating and assuring sustained protection of human health and the environment. This report presents the basis and justification for the completion of the subsurface component of the Amchitka Underground Nuclear Test Sites: Long Shot, Milrow, and Cannikin (hereafter referred to as the “Amchitka Site”).

The objectives of this report are to: 1) document the bases for the completion recommendation, and 2) define the long-term surveillance and maintenance strategy. Site monitoring, groundwater modeling and assessment, and surface cleanup conducted since 1971 form the basis for the completion recommendation.

This report consists of the following three major sections:

Section 1.0 - Provides an introduction to the site including: a background of historical as well as future use of the site; a description of the physical environment at Amchitka; historical site investigation reports throughout 2004 with groundwater modeling; and the regulations applicable to the site.

Section 2.0 - Describes the site completion justification including a discussion of current risk assessments, independent science studies (conducted in 2004 and 2005), and modeling.

Section 3.0 - Provides the site completion recommendation and strategy describing institutional controls, public participation, and long-term surveillance and maintenance.

\subsection{Background}

The following sections identify the location of Amchitka Island and present a high level summary of the historic, current, and planned future use of the island. 


\subsubsection{Location}

Amchitka Island is located near the far west end of the Aleutian Islands, approximately 1,340 miles (mi) west-southwest of Anchorage, Alaska (Figures 1-1 and 1-2). The island is $42 \mathrm{mi}$ long and from 1 to $4 \mathrm{mi}$ wide, with a total area of approximately 116 square miles (mi). It is bound by the Bering Sea to the north and by the Pacific Ocean to the south.

\subsubsection{Historic Uses}

The Aleutian Islands were set aside from the public domain as a wildlife reserve by President Taft in 1913 to provide a breeding ground for native birds, the propagation of reindeer and fur-bearing animals, and the encouragement and development of the fisheries. The establishment of the reserve also specifically stated that it "shall not interfere with the use of the islands for lighthouse, military, or naval purposes.” In 1940, the reserve was renamed the Aleutian Islands National Wildlife Refuge.

From World War II until the early 1990s, the island was used by multiple U.S. government agencies for a variety of military and research activities. During the late 1960s and early 1970s, drilling was performed in support of three deep subsurface nuclear tests conducted on Amchitka by the U.S. Department of Defense (DoD) and the U.S. Atomic Energy Commission (AEC) (predecessor agency to DOE).

There are numerous historic sites relating to the major occupations on the island, which include World War II U.S. Armed Forces, AEC/DOE nuclear testing period, and U.S. Navy Radar Station Operations.

The World War II facilities were the subject of a U.S. Army Corps of Engineers cleanup effort in 1986. At that time, several buildings were left in place because of potential historic significance, including the North and South Hangars, the Officer's Club, and the Chapel. The U.S. Navy subsequently demolished the North Hangar. The Chapel and the Officer's Club are collapsed, or nearly so, and no cleanup of these structures was attempted. The South Hangar, potentially eligible for inclusion on the National Register of Historic Places, was removed.

The nuclear testing period buildings, dating from the mid to late 1960s, were demolished (including some that were reused by the U.S. Navy during the radar station operations). They were not 
architecturally significant and were not eligible for inclusion on the National Register. The landscapes of the three surface ground zeroes (SGZs) were eligible. During 1972 and 1973, site reclamation efforts, a number of test-related wells were plugged and abandoned leaving only the wells identified as part of the Long-Term Hydrologic Monitoring program. These wells, locations, depths and abandonment method are identified in Table 1-2. The U.S. Navy demolished and removed all DoD buildings on the island in the summer of 2001. Also in 2001, the DOE conducted a series of surface mud pit closures and the final plugging and abandonment of the Long-Term Hydrologic Monitoring Program wells. Of the 24 monitoring wells, 16 were plugged and abandoned, 2 were protective covered, and 6 were either not found (under water) or the well structure and casing deteriorated to the point that plugging the well was not needed or possible. Details associated with each well are described in Table 1-2. 


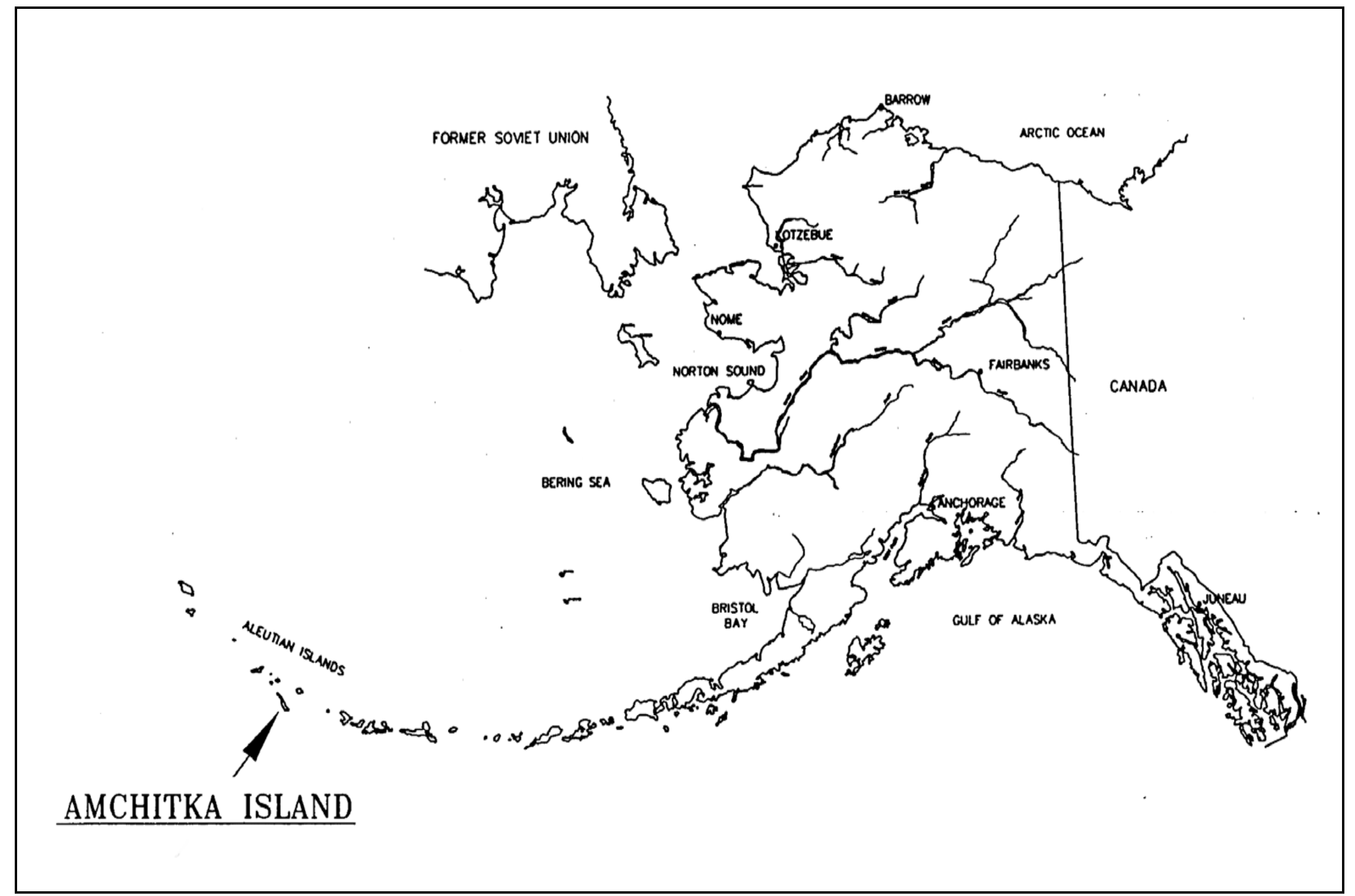

Figure 1-1

Aleutian Islands and Amchitka Island 


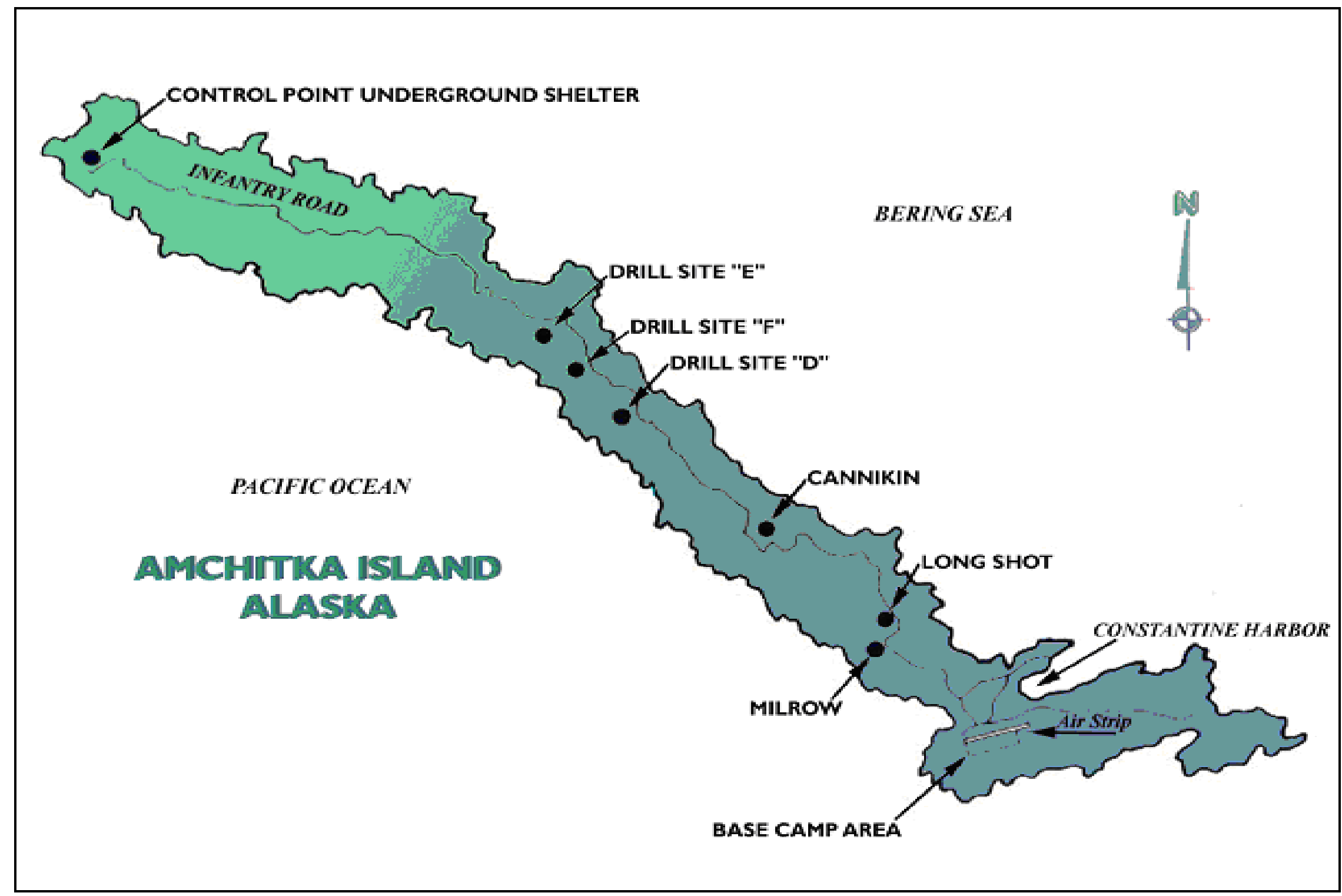

Figure 1-2

Amchitka Island Showing Drilling and Test Sites 
Finally, the U.S. Navy’s buildings from the 1987 to 1993 period are not considered eligible for inclusion on the National Register because the antenna system did not become operational until after 1989, the defined end of the Cold War era.

Table 1-1 presents historical activities on Amchitka Island.

\section{Table 1-1 \\ Amchitka Island Site History}

(Page 1 of 2)

\begin{tabular}{|c|c|}
\hline Date & Action \\
\hline 1868 & America purchased Russian America, which included the Aleutian Islands. \\
\hline 3/3/1913 & $\begin{array}{l}\text { President Taft issued Executive Order } 1733 \text {, setting the Aleutian Islands aside "... as a } \\
\text { preserve and breeding ground for native birds ...," with the stipulation that “... this } \\
\text { designation would not interfere with use for lighthouses, military or naval purposes" } \\
\text { (Federal Register, 1913). }\end{array}$ \\
\hline $1 / 1943$ & Began construction of the forward air base on Amchitka. \\
\hline $8 / 1950$ & Amchitka abandoned by the U.S. Army. \\
\hline 1951 & $\begin{array}{l}\text { The U.S. Department of Defense }(\mathrm{DoD}) \text { drilled } 34 \text { test holes for Project Windstorm; } \\
\text { however, the project was conducted at the Nevada Test Site. }\end{array}$ \\
\hline $1959-1961$ & White Alice communication system was operational. \\
\hline $4 / 1964$ & $\begin{array}{l}\text { The U.S. Atomic Energy Commission (AEC) picked the preliminary Long Shot Project } \\
\text { Site. }\end{array}$ \\
\hline $5 / 5 / 1964$ & Long Shot test planning began. \\
\hline $5 / 16-12 / 4,1964$ & Exploratory drilling for Long Shot was conducted. \\
\hline $2 / 3 / 1964$ & Rat Island earthquake occurred. \\
\hline $6 / 2 / 1965$ & AEC and DoD signed a Memorandum of Agreement (MOA) for Long Shot. \\
\hline $10 / 29 / 1965$ & Long Shot test was conducted ( 80 kilotons at 2,297 feet [ft] below ground surface [bgs]). \\
\hline 1966 & Department of Interior (DOI) granted permission for AEC to use Amchitka. \\
\hline 1966 & Battelle Labs was contracted to conduct ecological studies on Amchitka. \\
\hline 1967 & Amchitka Bioenvironmental Program was initiated. \\
\hline 1967 & Holes for proposed testing were drilled at sites $D, E$, and F. \\
\hline 10/2/1969 & Milrow test was conducted (about 1 megaton at $4,003 \mathrm{ft}$ bgs). \\
\hline $6 / 12 / 1970$ & Draft Environmental Impact Statement (EIS) for Cannikin test was issued. \\
\hline $6 / 1971$ & Final EIS was issued for the Cannikin test. \\
\hline 1971 & Site $\mathrm{H}$ was prepared for drilling, but no drilling took place. \\
\hline $11 / 6 / 1971$ & Cannikin test was conducted (less than 5 megatons at $5,873 \mathrm{ft}$ bgs). \\
\hline $2 / 25 / 1972$ & Amchitka cleanup began. \\
\hline $5 / 19-21 / 1972$ & Holes related to Long Shot were plugged and abandoned. \\
\hline
\end{tabular}

\section{Uncontrolled When Printed}


Table 1-1

Amchitka Island Site History

(Page 2 of 2)

\begin{tabular}{|c|c|}
\hline Date & Action \\
\hline $9 / 19-26 / 1972$ & All remaining holes were plugged and abandoned. \\
\hline 1973 & AEC demolished approximately 400 World War II buildings. \\
\hline 9/1973 & $\begin{array}{l}\text { U.S. Fish and Wildlife Services (USFWS) signed off on completion of } 120 \text { AEC disturbed } \\
\text { sites. }\end{array}$ \\
\hline $9 / 1973$ & AEC returned Amchitka Island to DOI. \\
\hline 1974 & Long Shot mud pits were left intact for monitoring purposes. \\
\hline 1974 & $\begin{array}{l}\text { Decontamination water from Cannikin test was injected into the chimney and } \\
\text { contaminated drilling tools were sealed in the re-entry hole. }\end{array}$ \\
\hline 1980 & $\begin{array}{l}\text { Alaska Maritime National Wildlife Refuge established 22,000 acres of Amchitka as a } \\
\text { wilderness area. }\end{array}$ \\
\hline $5 / 1986$ & U.S. Navy and USFWS signed an MOA for joint use of the island. \\
\hline 1993 & $\begin{array}{l}\text { U.S. Department of Energy (DOE) conducted sampling to evaluate potential chemical } \\
\text { impacts at disturbed sites. }\end{array}$ \\
\hline 1997 & Ecological and sediment testing were conducted for radionuclide impacts. \\
\hline 1998 & Further characterization of the mud pits was conducted. \\
\hline $6 / 2000$ & Engineering field study was conducted to assess remediation of mud pits. \\
\hline $12 / 2000$ & $\begin{array}{l}\text { USFWS issued EA and finding of no significant impact; report assigned remediation } \\
\text { responsibilities to DOE, U.S. Navy, and U.S. Army Corps of Engineers. }\end{array}$ \\
\hline $5 / 25 / 2001$ & $\begin{array}{l}\text { Surface remediation activities (including mud pit caps and underground storage tank } \\
\text { removal) began. }\end{array}$ \\
\hline Summer 2001 & $\begin{array}{l}16 \text { wells were plugged and abandoned, } 6 \text { could not be found, } 2 \text { wells (GZ-1, GZ-2) were } \\
\text { covered and locked, and } 1 \text { well (UAe-7e/h) was left open as a possible future monitoring } \\
\text { well. The GZ-1, GZ-2, and UAe-7e/h wells were located during the } 2006 \text { Mud Pit Cap } \\
\text { Inspection and the above status was verified. No other DOE wells exist on site and none } \\
\text { are being monitored. The U.S. Navy demolished and removed all DoD buildings on the } \\
\text { island. }\end{array}$ \\
\hline $9 / 10 / 2001$ & Surface remediation work was completed. \\
\hline $10 / 13 / 2001$ & Field base camp was demobilized. \\
\hline 2002 & $\begin{array}{l}\text { Evaluated groundwater flow and transport of radionuclides and presented findings in } \\
\text { Modeling Groundwater Flow and Transport of Radionuclides at Amchitka Island's } \\
\text { Underground Nuclear Tests: Milrow, Long Shot and Cannikin (NNSA/NV, 2002). }\end{array}$ \\
\hline $7 / 2003$ & Submitted Amchitka Island Surface Closure Report (NNSA/NSO, 2003). \\
\hline $8 / 2006$ & $\begin{array}{l}\text { First 5-year cap inspection was completed. No deterioration of mud pit caps was noted. } \\
\text { Report pending. }\end{array}$ \\
\hline
\end{tabular}

\section{Uncontrolled When Printed}


Table 1-2

Well Abandonment Details

(Page 1 of 5 )

\begin{tabular}{|c|c|c|c|c|}
\hline Date & Site & Well & Depth & Activity \\
\hline $9 / 72$ & Site F & UA-3 & $531 \mathrm{ft}$ & $\begin{array}{l}\text { Concrete removed from } 92 \text {-inch (in.) casing. Disconnected all } 2 \text {-in. pipe lines, } 90 \text {-in. wooden plug } \\
\text { installed. Poured } 2 \text {-foot (ft) cement cap on top of the gravel in the rat and mouse holes and mud trough } \\
\text { with } 8 \text { cubic feet }\left(\mathrm{ft}^{3}\right) \text { of slurry. Abandonment complete. }\end{array}$ \\
\hline $9 / 72$ & & UAE-3 & $7,012 \mathrm{ft}$ & $\begin{array}{l}\text { Removed dirt from around the } 133 / 8 \text {-in. outside diameter (O.D.) casing and found cement } 1 \mathrm{ft} \text { bgs. } \\
\text { Released pressure on casing head. Cemented to pad level with } 2 \mathrm{ft}^{3} \text { of slurry on top of the } 95 / 8 \text {-in. } \\
\text { O.D. casing. Abandonment complete. }\end{array}$ \\
\hline $9 / 72$ & Site D & UA-6 & $4,550 \mathrm{ft}$ & Cemented from top of 92 -in. casing to pad level 144 in. diameter. Abandonment complete. \\
\hline $9 / 72$ & Site $D$ & UAE-6C & $6,999 \mathrm{ft}$ & $\begin{array}{l}\text { Wooden plug placed at ground level minus } 10 \mathrm{ft} \text {. Cemented } 10-\mathrm{ft} \text { plug inside } 133 / 8 \text {-in. casing with } \\
\text { cement and sand slurry. Abandonment complete. }\end{array}$ \\
\hline $9 / 72$ & Sites E\&F & & & $\begin{array}{l}\text { Gravel and sand in both sides, rat holes, mouse holes, and suction trough pads. Poured cement on } \\
\text { both sites. No problems with cementing plug. }\end{array}$ \\
\hline $9 / 72$ & & UA-7 & $100 \mathrm{ft}$ & $\begin{array}{l}\text { The 144-in. inside diameter (I.D.) conductor casing and rat hole were filled with sand and gravel to } \\
2 \mathrm{ft} \text { bgs. Cemented mud trough and rat hole to pad level with } 43 \mathrm{ft}^{3} \text { of cement slurry. Abandonment } \\
\text { complete. }\end{array}$ \\
\hline 9/72 & Site C & UAE-1 & $7,000 \mathrm{ft}$ & $\begin{array}{l}\text { Cut off the } 95 / 8 \text { - and } 13-3 / 8 \text {-in. O.D. casing to } 1 \mathrm{ft} \text { bgs. Welded plate with hole marker on top of the } \\
20 \text {-in. O.D. casing. Filled from ground level to minus } 2 \mathrm{ft} \text { using } 18-\mathrm{ft}^{3} \text { sand-cement slurry. } \\
\text { Abandonment complete }\end{array}$ \\
\hline 9/72 & Site $C$ & UA-1 & $6,150 \mathrm{ft}$ & $\begin{array}{l}\text { Cut } 103 / 4 \text {-in. O.D. casing beneath the strongback and removed from top of the } 9 \text {-in. I.D. casing. } \\
\text { Concrete was removed from around the } 92 \text {-in. casing to } 1 \mathrm{ft} \text { bgs. Cut off } 5 \text {-ft section of } 92 \text {-in. casing to } \\
1 \mathrm{ft} \text { bgs. Removed concrete from around the } 54 \text {-in. I.D. casing to } 1 \mathrm{ft} \text { bgs. Cut off } 54 \text {-in. I.D. casing to } \\
1 \mathrm{ft} \text { bgs. Removed from hole, cleaned out stemming sand. Cut cables below top of } 54 \text {-in. casing. Cut } \\
\text { off } 103 / 4 \text {-in. O.D. casing to } 1 \mathrm{ft} \text { bgs. Welded } 1 / 2 \text {-in. plate to top of } 92 \text {-in. I.D. casing. Poured cement } \\
\text { cap from ground level minus } 1 \mathrm{ft} \text { to pad level. Sand and cement slurry used }-81 \mathrm{ft}^{3} \text {. Poured } 2 \text {-ft } \\
\text { cement cap on } 24 \text {-in. rat hole. Abandonment complete. }\end{array}$ \\
\hline 9/72 & Site $C$ & UA-1-DW & $6,008 \mathrm{ft}$ & $\begin{array}{l}\text { Cut off plate on the } 95 / 8 \text {-in.O.D. casing. Installed wood bridge plug at } 10 \mathrm{ft} \text { inside the tubing with hook } \\
\text { on top. Backfilled with cement from } 2 \mathrm{ft} \text { bgs to ground level with cement and sand plug using } 18 \mathrm{ft}^{3} \text { of } \\
\text { sand-cement slurry. Abandonment complete. }\end{array}$ \\
\hline
\end{tabular}

\section{Uncontrolled When Printed}


Table 1-2

Well Abandonment Details

(Page 2 of 5 )

\begin{tabular}{|c|c|c|c|c|}
\hline Date & Site & Well & Depth & Activity \\
\hline $9 / 72$ & Site C & UA-1-GH-1 & $101 \mathrm{ft}$ & $\begin{array}{l}\text { Backfilled with cement and sand slurry from ground level minus } 1 \text { in. using } 9 \mathrm{ft}^{3} \text {. Abandonment } \\
\text { complete. }\end{array}$ \\
\hline $9 / 72$ & Site B & UA-2-I-2 & $370 \mathrm{ft}$ & $\begin{array}{l}\text { Removed cement from } 133 / 8 \text {-in. casing to } 1 \mathrm{ft} \text { bgs. Welded steel plate with } 4 \text {-in. by } 5 \text {-ft marker to } \\
133 / 8 \text {-in. casing. Cemented to surface with } 5 \mathrm{ft}^{3} \text { of sand-cement slurry. Abandonment complete. }\end{array}$ \\
\hline $9 / 72$ & Site B & UA-2 & $4,030 \mathrm{ft}$ & $\begin{array}{l}\text { Welded } 1 / 2 \text {-in. plate over casing; placed rebar over plate. Chipped cement from pad level to minus } 2 \mathrm{ft} \\
\text { Cut off } 133 / 8 \text {-in. casing at } 2 \mathrm{ft} \text { bgs. Welded plate with } 4 \text {-in. by } 5 \text { - } \mathrm{ft} \text { marker on } 133 / 8 \text {-in. pipe. } \\
\text { Cemented to ground level with } 3 \mathrm{ft}^{3} \text { of slurry. Poured cement and sand plug from top of } 36 \text {-in. casing to } \\
\text { pad level ( } 130 \mathrm{ft}) ; 90 \mathrm{ft}^{3} \text { of slurry used on the top plug. Abandonment complete. }\end{array}$ \\
\hline $9 / 72$ & $\begin{array}{l}\text { Long Shot } \\
\text { Emplacement } \\
\text { Hole }\end{array}$ & & & $\begin{array}{l}\text { Cleaned up surface pad at Ground Zero. Removed cement from around 74-in. casing. Cut off casing } \\
1 \mathrm{ft} \text { bgs. Removed cement from } 74-\text { to } 54 \text {-in. casing } 1 \mathrm{ft} \text { bgs. Abandonment complete. }\end{array}$ \\
\hline $9 / 72$ & Site C & UA-1-GH-2 & $100 \mathrm{ft}$ & $\begin{array}{l}\text { Backfilled with cement and sand slurry from ground level minus } 1 \mathrm{ft} \text { using } 9 \mathrm{ft}^{3} \text { of slurry. Abandonment } \\
\text { complete. }\end{array}$ \\
\hline $9 / 72$ & Site C & $\begin{array}{l}\text { Small 65/8-ft } \\
\text { Hole }\end{array}$ & & $\begin{array}{l}\text { (Hole used at RTP Pad for generator) From ground level to minus } 3 \mathrm{ft} \text { with slurry. Abandonment } \\
\text { complete. }\end{array}$ \\
\hline 9/72 & Site C & & & Completely abandoned. \\
\hline 9/72 & Site B & UA-2-I-1 & $6,500 \mathrm{ft}$ & $\begin{array}{l}\text { Poured cement plug from top marker plate. Welded } 13 \text { 3/8-in. casing at ground level. } 5 \mathrm{ft}^{3} \text { of slurry } \\
\text { used. Abandonment complete. }\end{array}$ \\
\hline $9 / 72$ & $\begin{array}{l}\text { Long Shot } \\
\text { Ground Zero }\end{array}$ & & & $\begin{array}{l}\text { Cut off } 54 \text {-in. casing } 1 \mathrm{ft} \text { bgs. Removed all cement from } 54 \text { to } 36 \mathrm{in} \text {. Cut off } 36 \text {-in. casing } 1 \mathrm{ft} \text { bgs. } \\
\text { Welded } 1 / 2 \text {-in. plate over all casing to } 74 \text {-in. casing. Placed } 5 \text { pieces of } 11 / 2 \text {-in. rebar extending over } \\
\text { 74-in. plate covered with } 2 \mathrm{ft} \text { cement. Abandonment complete. }\end{array}$ \\
\hline 9/72 & Long Shot GZ & $\mathrm{EH}-1$ & $1,606 \mathrm{ft}$ & $\begin{array}{l}\text { The name plate for this hole was welded to a } 4 \text {-ft drill pipe marker at the side of Infantry Road. This } \\
\text { location was in the middle of the road, and the casing was plugged with cement previously and cut off } \\
\text { below the level of the road. Abandonment complete. }\end{array}$ \\
\hline 9/72 & Long Shot GZ & $\mathrm{EH}-2$ & $519 \mathrm{ft}$ & $\begin{array}{l}\text { Welded } 4 \text { in. by } 5 \text {-ft marker plate and welded plate to } 85 / 8 \text { in. casing. Plugged with } 20 \mathrm{ft}^{3} \text { of cement. } \\
\text { Abandonment complete. }\end{array}$ \\
\hline 9/72 & Long Shot GZ & $\mathrm{EH}-3$ & $2,801 \mathrm{ft}$ & Excavated around $133 / 8$-in. casing to $1 \mathrm{ft}$ bgs, plugged with $6 \mathrm{ft}^{3}$ of cement. Abandonment complete. \\
\hline
\end{tabular}

\section{Uncontrolled When Printed}


Table 1-2

Well Abandonment Details

(Page 3 of 5)

\begin{tabular}{|c|c|c|c|c|}
\hline Date & Site & Well & Depth & Activity \\
\hline $9 / 72$ & Long Shot GZ & $\mathrm{EH}-4$ & $1,146 \mathrm{ft}$ & $\begin{array}{l}\text { Drained water from around location. Excavated around } 13 \text { 3/8-in. casing, plugged with } 4 \mathrm{ft}^{3} \text { of cement. } \\
\text { Abandonment complete. }\end{array}$ \\
\hline $9 / 72$ & Long Shot GZ & $\mathrm{EH}-5$ & $2,607 \mathrm{ft}$ & $\begin{array}{l}\text { Cut casing off } 1 \mathrm{ft} \text { bgs, also cut cables } 1 \mathrm{ft} \text { bgs. Welded } 1 / 2 \text {-in. plate with } 4 \text {-in. by } 5 \mathrm{ft} \text {-type marker to } \\
133 / 8 \text {-in. casing, plugged with } 20 \mathrm{ft}^{3} \text { of cement. Abandonment complete. }\end{array}$ \\
\hline $9 / 72$ & Long Shot GZ & $\mathrm{EH}-6$ & Unknown & $\begin{array}{l}\text { Drained water from around location. Excavated around } 13 \text { 3/8-in. casing, plugged with } 4 \mathrm{ft}^{3} \text { of cement. } \\
\text { Abandonment complete. }\end{array}$ \\
\hline 9/72 & Long Shot & & $10 \mathrm{ft}$ & Long Shot GZ - plugged with $81 \mathrm{ft}^{3}$ of cement. Abandonment complete. \\
\hline $5 / 73$ & Long Shot & $\mathrm{OH}-9$ & $124 \mathrm{ft}$ & $\begin{array}{l}10 \text {-ft cement plug; } 0.857 \mathrm{ft}^{3} \text { cement in hole. Welded } 14 \mathrm{in} \text {. by } 1 / 2 \text { in. to each } 13 \text { 3/8-in. casing. } \\
\text { Cemented to } 1 \mathrm{ft} \text { bgs. Abandonment complete. }\end{array}$ \\
\hline $5 / 73$ & Long Shot & $\mathrm{OH}-8$ & $124 \mathrm{ft}$ & $\begin{array}{l}10 \text {-ft cement plug; } 0.857 \mathrm{ft}^{3} \text { cement in hole. Welded } 14 \text { by } 1 / 2 \text { in. to each } 133 / 8 \text {-in. casing. Cemented } \\
\text { to } 1 \mathrm{ft} \text { bgs. Abandonment complete. }\end{array}$ \\
\hline $5 / 73$ & Long Shot & $\mathrm{OH}-7$ & $123 \mathrm{ft}$ & $\begin{array}{l}10 \text {-ft cement plug; } 0.857 \mathrm{ft}^{3} \text { cement in hole. Welded } 14 \text { by } 1 / 2 \text { in. to each } 133 / 8 \text {-in. casing. Cemented } \\
\text { to } 1 \mathrm{ft} \text { bgs. Abandonment complete. }\end{array}$ \\
\hline $5 / 73$ & Long Shot & $\mathrm{OH}-6$ & $120 \mathrm{ft}$ & $\begin{array}{l}10 \text {-ft cement plug; } 0.857 \mathrm{ft}^{3} \text { cement in hole. Welded } 14 \text { by } 1 / 2 \text { in. to each } 133 / 8 \text {-in. casing. Cemented } \\
\text { to } 1 \mathrm{ft} \text { bgs. Abandonment complete. }\end{array}$ \\
\hline $5 / 73$ & Long Shot & $\mathrm{OH}-5$ & $124 \mathrm{ft}$ & $\begin{array}{l}10 \text {-ft cement plug; } 0.857 \mathrm{ft}^{3} \text { cement in hole. Welded } 14 \mathrm{in.} \text { by } 1 / 2 \text { in. to each } 133 / 8 \text {-in. casing. } \\
\text { Cemented to } 1 \mathrm{ft} \text { bgs. Abandonment complete. }\end{array}$ \\
\hline $5 / 73$ & Long Shot & $\mathrm{OH}-4$ & $119 \mathrm{ft}$ & $\begin{array}{l}10 \text {-ft cement plug; } 0.857 \mathrm{ft}^{3} \text { cement in hole. Welded } 14 \text { in. by } 1 / 2 \text { in. to each } 13 \text { 3/8-in. casing. } \\
\text { Cemented to } 1 \mathrm{ft} \text { bgs. Abandonment complete. }\end{array}$ \\
\hline $5 / 73$ & Long Shot & $\mathrm{OH}-3$ & $124 \mathrm{ft}$ & $\begin{array}{l}10 \text {-ft cement plug; } 0.857 \mathrm{ft}^{3} \text { cement in hole. Welded } 14 \mathrm{in} \text {. by } 1 / 2 \mathrm{in.} \text { to each } 133 / 8 \text {-in. casing. } \\
\text { Cemented to } 1 \mathrm{ft} \text { bgs. Abandonment complete. }\end{array}$ \\
\hline $5 / 73$ & Long Shot & UDH-8 & $123 \mathrm{ft}$ & $\begin{array}{l}10-\mathrm{ft} \text { cement plug; } 0.857 \mathrm{ft}^{3} \text { cement in hole. Welded } 14 \mathrm{ft} \text { by } 1 / 2 \mathrm{in.} \mathrm{to} \mathrm{each} 133 / 8 \mathrm{in} \text {. casing. Cemented } \\
\text { to } 1 \mathrm{ft} \text { bgs. Abandonment complete. }\end{array}$ \\
\hline $5 / 73$ & Long Shot & UDH-2 & $525 \mathrm{ft}$ & $\begin{array}{l}10 \text {-ft cement plug; } 0.857 \mathrm{ft}^{3} \text { cement in hole. Welded } 14 \text { in. by } 1 / 2 \text { in. to each } 133 / 8 \text {-in. casing. } \\
\text { Cemented to } 1 \mathrm{ft} \text { bgs. Abandonment complete. }\end{array}$ \\
\hline
\end{tabular}

\section{Uncontrolled When Printed}


Table 1-2

Well Abandonment Details

(Page 4 of 5)

\begin{tabular}{|c|c|c|c|c|}
\hline Date & Site & Well & Depth & Activity \\
\hline $5 / 73$ & Long Shot & $\begin{array}{l}\text { Eff. Eval. } \\
\text { Hole \#1 }\end{array}$ & $700 \mathrm{ft}$ & $\begin{array}{l}3.5 \mathrm{ft}^{3} \text { cement in Eff. Eval. Hole \#1. Welded } 14 \text { in. by } 1 / 2 \text { in. to each } 133 / 8 \text {-in. casing. Cemented to } \\
1 \mathrm{ft} \text { bgs. Abandonment complete. }\end{array}$ \\
\hline $7 / 01$ & Milrow & W-2 & $1.0 \mathrm{ft}$ & $\begin{array}{l}\text { Shallow well pulled out of ground; hole filled w/ sodium bentonite chips; remaining casing in ground } \\
\text { filled } w / \text { bentonite chips. Abandonment complete. }\end{array}$ \\
\hline $7 / 01$ & Milrow & W-3 & $3.7 \mathrm{ft}$ & $\begin{array}{l}\text { Shallow well pulled out of ground; hole filled w/ sodium bentonite chips; remaining casing in ground } \\
\text { filled } w / \text { bentonite chips. Abandonment complete. }\end{array}$ \\
\hline $7 / 01$ & Milrow & $W-4$ & $<10 \mathrm{ft}$ & $\begin{array}{l}\text { Shallow well pulled out of ground; hole filled w/ sodium bentonite chips; remaining casing in ground } \\
\text { filled w/ bentonite chips. Abandonment complete. }\end{array}$ \\
\hline $7 / 01$ & Milrow & W-5 & $3.0 \mathrm{ft}$ & $\begin{array}{l}\text { Shallow well pulled out of ground; hole filled w/ sodium bentonite chips; remaining casing in ground } \\
\text { filled } w / \text { bentonite chips. Abandonment complete. }\end{array}$ \\
\hline $7 / 01$ & Milrow & W-6 & $3.5 \mathrm{ft}$ & $\begin{array}{l}\text { Shallow well pulled out of ground; hole filled w/ sodium bentonite chips; remaining casing in ground } \\
\text { filled } w / \text { bentonite chips. Abandonment complete. }\end{array}$ \\
\hline $7 / 01$ & Milrow & W-7 & $2.4 \mathrm{ft}$ & $\begin{array}{l}\text { Shallow well pulled out of ground; hole filled w/ sodium bentonite chips; remaining casing in ground } \\
\text { filled } w / \text { bentonite chips. Abandonment complete. }\end{array}$ \\
\hline $7 / 01$ & Milrow & W-8 & $5.1 \mathrm{ft}$ & $\begin{array}{l}\text { Shallow well pulled out of ground; hole filled w/ sodium bentonite chips; remaining casing in ground } \\
\text { filled w/ bentonite chips. Abandonment complete. }\end{array}$ \\
\hline $7 / 01$ & Milrow & W-9 & $<10 \mathrm{ft}$ & $\begin{array}{l}\text { Shallow well }(<10 \mathrm{ft}) \text { pulled out of ground; hole filled } \mathrm{w} / \text { sodium bentonite chips; remaining casing in } \\
\text { ground filled } \mathrm{w} / \text { bentonite chips. Abandonment complete. }\end{array}$ \\
\hline $7 / 01$ & Milrow & $W-10$ & $6.7 \mathrm{ft}$ & Not found under water. \\
\hline $7 / 01$ & Milrow & W-11 & $4.8 \mathrm{ft}$ & $\begin{array}{l}\text { Shallow well }(<10 \mathrm{ft} \text { ) pulled out of ground; hole filled } \mathrm{w} / \text { sodium bentonite chips; remaining casing in } \\
\text { ground filled } \mathrm{w} / \text { bentonite chips. Abandonment complete. }\end{array}$ \\
\hline $7 / 01$ & Milrow & W-12 & $<10 \mathrm{ft}$ & $\begin{array}{l}\text { Shallow well }(<10 \mathrm{ft}) \text { pulled out of ground; hole filled } \mathrm{w} / \text { sodium bentonite chips; remaining casing in } \\
\text { ground filled } \mathrm{w} / \text { bentonite chips. Abandonment complete. }\end{array}$ \\
\hline $7 / 01$ & Milrow & W-13 & $3.4 \mathrm{ft}$ & Not found under water. \\
\hline $7 / 01$ & Milrow & $W-14$ & $<10 \mathrm{ft}$ & $\begin{array}{l}\text { Shallow well }(<10 \mathrm{ft}) \text { pulled out of ground; hole filled } w / \text { sodium bentonite chips; remaining casing in } \\
\text { ground filled } w / \text { bentonite chips. Abandonment complete. }\end{array}$ \\
\hline
\end{tabular}

\section{Uncontrolled When Printed}


Table 1-2

Well Abandonment Details

(Page 5 of 5 )

\begin{tabular}{|c|c|c|c|c|}
\hline Date & Site & Well & Depth & Activity \\
\hline $7 / 01$ & Milrow & $W-15$ & $3.7 \mathrm{ft}$ & Not found under water \\
\hline $7 / 01$ & Milrow & $W-16$ & $<10 \mathrm{ft}$ & $\begin{array}{l}\text { Shallow well }(<10 \mathrm{ft}) \text { pulled out of ground; hole filled } \mathrm{w} / \text { sodium bentonite chips; remaining casing in } \\
\text { ground filled } \mathrm{w} / \text { bentonite chips. Abandonment complete. }\end{array}$ \\
\hline $7 / 01$ & Milrow & $W-17$ & $<10 \mathrm{ft}$ & $\begin{array}{l}\text { Shallow well }(<10 \mathrm{ft}) \text { pulled out of ground; hole filled } \mathrm{w} / \text { sodium bentonite chips; remaining casing in } \\
\text { ground filled } \mathrm{w} / \text { bentonite chips. Abandonment complete. }\end{array}$ \\
\hline $7 / 01$ & Milrow & W-18 & $1.8 \mathrm{ft}$ & Not found under water \\
\hline $7 / 01$ & Milrow & W-19 & $3.0 \mathrm{ft}$ & $\begin{array}{l}\text { Shallow well }(<10 \mathrm{ft}) \text { pulled out of ground; hole filled } \mathrm{w} / \text { sodium bentonite chips; remaining casing in } \\
\text { ground filled } \mathrm{w} / \text { bentonite chips. Abandonment complete. }\end{array}$ \\
\hline $7 / 01$ & Long Shot & WL-1 & $8.2 \mathrm{ft}$ & Removed PVC well casing and fill with bentonite. Abandonment complete. \\
\hline $7 / 01$ & Long Shot & WL-2 & $11.5 \mathrm{ft}$ & Removed PVC well casing and fill with bentonite. Abandonment complete. \\
\hline $7 / 01$ & Long Shot & GZ-1 & $100 \mathrm{ft}$ & Protective cover and lock \\
\hline $7 / 01$ & Long Shot & GZ-2 & $50 \mathrm{ft}$ & Protective cover and lock \\
\hline $7 / 01$ & Long Shot & EPA-1 & $253 \mathrm{ft}$ & Well casing was deteriorated beyond plugging \\
\hline $7 / 01$ & Cannikin & HTH-3 & $152 \mathrm{ft}$ & Well casing was deteriorated beyond plugging \\
\hline
\end{tabular}


Three underground nuclear tests were conducted on Amchitka Island in 1965, 1969, and 1971. These tests were respectively designated Long Shot, Milrow, and Cannikin. Long Shot was detonated at a depth of 2,297 feet (ft) and had an 80-kiloton yield (DOE, 1988). It was detonated shortly after a nearby 8.7 magnitude earthquake as part of the Vela Uniform project to determine whether monitoring techniques could differentiate between natural seismicity and nuclear explosions. After a screening process conducted subsequent to Long Shot, Amchitka Island was selected as one of the Supplemental Test Sites (the other was in Central Nevada) for testing higher yield underground nuclear explosives that could not be tested at the Nevada Test Site (NTS) due to the impact of ground motion on high-rise buildings in Las Vegas. Milrow was a seismic calibration test detonated at a depth of 4,003 ft, with about a 1 megaton yield. Cannikin was detonated at a depth of 5,873 ft, with a yield of less than 5 megatons. In addition to these three tests, drilling was performed at three other sites (D, E, and F) where nuclear testing was considered but not performed. The locations of all six sites are indicated on Figure 1-2.

The tests, conducted at depths ranging from 2,300 to 5,875 ft below ground surface (bgs), created a subsurface cavity around the center of each detonation and a chimney of fragmented and collapsed rock above. The cavities and chimneys contain radioactive by-products of the nuclear detonations, some of which were trapped in fused rock created when rock melted by the detonations cooled and hardened.

\subsubsection{Current and Future Use}

Amchitka is part of the Aleutian Islands Unit of the Alaska Maritime National Wildlife Refuge (AMNWR), which is administered by the U.S. Fish and Wildlife Service (USFWS). The island will remain under the jurisdiction of the USFWS for the foreseeable future and is currently uninhabited. The island, which is accessible by air and ship, is not currently used for commercial or active military purposes. Fishermen and other mariners infrequently visit the island for recreational purposes. The Alaska Volcano Observatory recently installed an automated communications station on Amchitka to relay data from seismic monitoring equipment located on several neighboring islands. The Corps of Engineers is planning for site visits within the next 5 years to locate and remove unexploded ordnance. Foreseeable future land uses include limited on-site activities by USFWS and research partners in support of the refuge's wildlife conservation and wilderness purposes. Limited visits by 
recreational and subsistence users are anticipated to continue. The original establishing order that provided for military purposes will remain in effect. The DoD retains the right to use the island, if determined necessary, for national defense purposes.

\subsection{Physical Environment}

The island's coastline is very rugged with sea cliffs, isolated sandy and gravel beaches, and grassy slopes. The lowest elevations are on the eastern third of the island and are characterized by isolated, shallow ponds and heavily vegetated drainages. The central portion of the island has higher elevations, is more prone to wind erosion, and has fewer lakes. The westernmost three miles of the island are barren. The area contains a windswept rocky plateau with sparse vegetation, except for those areas (e.g., stream drainages) protected from the wind. The average surface elevation at the western end of the island is approximately $800 \mathrm{ft}$. The highest elevation on the island is approximately $1,600 \mathrm{ft}$.

\subsubsection{Climate}

Amchitka Island is characterized by a pronounced maritime climate, including frequent storms, strong winds, and often-cloudy skies. There is no prevailing wind direction, although during the summer months the winds are generally out of the southwest. The mean wind speed between December and February is 30 miles per hour (mph); between March and May it is 26 mph; between June and August it is $22 \mathrm{mph}$; and between September and November it is $27 \mathrm{mph}$. The maximum-recorded wind velocity on Amchitka is $115 \mathrm{mph}$. The ocean moderates temperatures, which average 31 degrees Fahrenheit $\left({ }^{\circ} \mathrm{F}\right.$ ) in winter (January) and $48^{\circ} \mathrm{F}$ in summer (August). Annual precipitation is about 33 inches (in.), including approximately 71 in. of snow.

\subsubsection{Geology}

Amchitka Island apparently formed in early Tertiary time (roughly 50 million years ago) as a result of tectonic uplift and deposition of volcanic flow and marine sediments collectively known as the Amchitka Formation. Amchitka is located in the Aleutian arc, a 3500-km long chain of volcanoes produced by subduction (one plate is thrust beneath another) of the Pacific plate beneath the North American plate. The Pacific plate thrusts underneath the North American plate at a rate that varies from 6-8 centimeters per year ( $\mathrm{cm} /$ year), with the rate increasing to the west, and the direction of 
plate convergence becoming more oblique to the Aleutian trench in the west. Tectonic activity can impact subsurface fluid flow directly through slip on local faults, or indirectly through strong shaking or changes in the stress field resulting from strong earthquakes nearby.

A combination of geological evidence, submarine mapping, and new site velocities measured with the Global Positioning System (GPS) suggests that Amchitka Pass, immediately to the east of Amchitka island, is a site of concentrated extension, and that west of Amchitka Pass there are major strike-slip faults located within or north of the arc (Freymueller et al., 2002). The GPS data show that the most reasonable model would have fault slip rates on the order of $2 \mathrm{~cm} /$ year on extensional faults within Amchitka Pass and strike-slip faults to the north of Amchitka. For comparison, this rate is about $1 / 2$ to $2 / 3$ as fast as the San Andreas Fault system in California, and one to two orders of magnitude more rapid than the slip rates on faults within or near the Nevada Test Site or the proposed Yucca Mountain storage facility.

Most of the island contains only a thin, discontinuous veneer of unconsolidated sediments overlying the volcanic bedrock. Over most of the island, organic soils, including peat, overlie the unconsolidated sediments. The principal organic soil on the island blankets much of the poorly drained areas, marine terraces and other topographically low areas, and contains constituent plant materials that have decomposed and often contain horizons of peat. In the most topographically depressed and wettest parts of the island, the soils are typically peaty, with a thick mat of vegetation and little organic decomposition. In the drier and topographically higher areas, the soils are folists (well-drained organic soil). Limited areas of poorly developed sandy soils exist in dune areas in a narrow strip along the Bering Sea coastal bluffs.

\subsubsection{Hydrology}

Amchitka Island is covered with hundreds of small, shallow ponds up to $330 \mathrm{ft}$ wide and up to $10 \mathrm{ft}$ deep. The smaller ponds are considerably shallower, typically ranging from 12 to 20 in. deep. Ponds are most numerous on the eastern two-thirds of the island (approximately 26 ponds per mi²), where they have developed above marine terraces and are confined by thick vegetation peat. Many lakes in this region lack a definite inlet or outlet. Fewer ponds are present on the western third of the island, where they typically occupy bedrock depressions. Larger pond sediments are either floc (suspension 
of low-density detrital organic material) over gravel, organic silts over gravel, or clean gravel. The bottoms of smaller ponds are usually composed of peat or fine sediment covered with floc.

Watersheds on Amchitka Island are generally limited to 1 to $3 \mathrm{mi}$ in length because all streams drain perpendicular to the long axis of the island into either the Bering Sea or the Pacific Ocean. Streams on the eastern part of the island flow slowly through tundra-covered watersheds, range from 3 to $10 \mathrm{ft}$ wide, are up to $12 \mathrm{in}$. deep, and are characterized by low gradients and flow velocities. Streams in the central and western regions range from 6 to $13 \mathrm{ft}$ wide and are up to $14 \mathrm{in}$. deep. Most of the streams in the island flow year-round. During relatively dry periods, stream flows are sustained by baseflow from soils and the underlying weathered bedrock; surface runoff and baseflow contribute to flows during wet periods.

The hydrogeology beneath the surface of Amchitka Island is governed by the dynamics of the saltwater intrusion typical of islands. The groundwater system consists of a freshwater lens floating on seawater. To sustain this lens, there must be active groundwater circulation. Rainfall that infiltrates is fresher, and less dense, than the underlying seawater. Continued recharge results in the buildup of a lens of fresh water floating above the seawater, and the flow of freshwater from the center of the island outward to the ocean. Groundwater flow is generally characterized by recharge along a shallow water table, downward flow in the interior of the island, and upward flow approaching the coast, with freshwater discharge in seeps along the sea floor. The nearly saturated subsurface conditions, combined with low hydraulic conductivity and high rainfall, leads to significant runoff and the development of shallow groundwater zones that rapidly discharge water in springs and seeps rather than allowing deep infiltration.

Data collected from shallow and deep boreholes on the island are consistent with this conceptual model of flow. Seven wells with depths of hundreds to over a thousand meters below land surface were drilled and tested in the 1960s and 1970s, as well as numerous shallow wells. These wells encountered fresh water at shallow depths and increasing salinity at greater depth (Beetem et al., 1971; U.S. Army Corps of Engineers and USGS, 1965). Static water levels declined in the wells with increasing depth below land surface (Ballance, 1970a,b, 1972a,b, and 1973a,b; Dudley, et al., 1977), indicating the potential for downward directed groundwater flow. Seventy four hydraulic tests were run in discrete intervals in the deep wells (Ballance, 1970a,b, 1972a,b, and 1973a,b; Ballance and 
Dinwiddie, 1972; U.S. Army Corps of Engineers and USGS, 1965); analysis of these tests (Hassan et al., 2002) is notable for a wide range of variability and overall relatively low values. Measurements of precipitation and stream gages noted a close relationship between surface water and shallow groundwater systems (Dudley et al., 1977; Gonzalez, 1977). Many of these data are presented and discussed in Hassan et al. (2002) and are also summarized by Dudley et al. (1977).

The water in streams, lakes, and springs on Amchitka Island is generally of excellent quality. However, the chemical character of surface water on the island is quite varied. The surface water generally has less than 200 milligrams per liter total dissolved solids, with sodium and chloride as the dominant cation and anion, respectively.

\subsection{Previous Investigations}

Amchitka Island has been the subject of many studies throughout its history. During the 1960s and 1970s, both before and after the underground nuclear tests were conducted, scientists carried out extensive investigations of the environment on Amchitka Island. Data collected from these investigations include information on the geology, hydrology, climate, geomorphology, and the land and marine biota of the island as well as information on environmental contaminants and the effects of nuclear testing. Table 1-3 provides selected references to island-wide investigations and individual studies. Some of these studies and investigations are summarized and discussed in the following sections.

\subsubsection{The Environment of Amchitka Island (Merritt and Fuller, 1977)}

The Amchitka Bioenvironmental Program was developed in support of the Amchitka Island underground nuclear tests, specifically the Milrow and Cannikin sites. The objectives of the program were to conduct appropriate field and laboratory studies to predict, evaluate, and document the effects on the bioenvironment of Amchitka Island that might result from the nuclear tests and to recommend measures for minimizing these effects. The program began in 1967, after the Long Shot test but before the Milrow test in 1969. It concluded in 1973, following completion of the Cannikin test.

The studies conducted under this program included climate, geology, hydrology, and biota. The Merritt and Fuller report presents a summary of these studies in a series of individual papers within 
the report, which are grouped into major sections on the land, the sea, marine mammals, and environmental contaminants. The report also includes a summary of the island setting (geographic, geologic, hydrologic, weather and climate, prehistoric human occupation, and previous scientific investigations) and a paper summarizing the observed and measured effects of the nuclear tests on the island.

The following sections present summaries of the major studies conducted as part of the Bioenvironmental Program.

\section{Ecological Consequences of Nuclear Testing (Fuller and Kirkwood, 1977)}

The detonations at Milrow and Cannikin and related activities resulted in the loss of or damage to terrestrial habitat totaling approximately 1.5 percent of the total area of Amchitka Island. A number of lakes and streams were temporarily affected by site activities but recovered quickly. Several freshwater areas of the island were irreversibly impacted, however, including channel alteration along one stream and the creation of a new lake. An intertidal bench was displaced to a level above the intertidal zone.

Localized terrestrial, freshwater, and marine ecosystem habitat losses were minor and had no permanent effects on the associated biotic populations. No plant or animal population on or around the island was lost or endangered, although substantial numbers of sea otters and freshwater and marine fish were killed by the Cannikin detonation. However, post-test studies indicated that these populations recovered quickly.

The detonations also produced scattered terrain disturbances around the island, some of which were severe in localized areas. In these instances, the landscape was visibly altered, and may remain so for decades or even centuries.

\section{Radionuclides in Air, Water, and Biota (Seymour and Nelson, 1977)}

Air, water, and biological samples were collected before and after the three underground nuclear detonations at Amchitka Island and were analyzed for natural and fallout radionuclides by gamma spectrometry. Select samples were also analyzed for tritium, iron-55, and strontium (Sr)-90. The primary objective of this study was to identify the origin of the fallout radionuclides (i.e., the Amchitka Island detonations versus natural background and/or other sources). 
Samples from 81 types of organisms were collected and analyzed for radionuclides potentially available to man through the food web from areas likely to be contaminated if seepage of radionuclides from the detonation sites occurred. The studies showed that there was no escape of radionuclides from the detonation sites except for trace amounts of radionuclides, primarily tritium, in water and soil gas samples from the immediate vicinity of the SGZ for the Long Shot test (see Section 1.3.2). In general, radionuclide values for Amchitka Island samples were similar to those from comparable samples from other geographical areas.

\section{Marine Fish Communities (Simenstad et al., 1977)}

The Fisheries Research Institute of the University of Washington studied and evaluated the impact of the Milrow and Cannikin tests on marine fish off Amchitka Island from the summer of 1967 to the fall of 1973. Information was collected on 92 fish species taken from marine waters around Amchitka Island, not only providing information to support the nuclear testing efforts, but also significantly expanding the knowledge of the Aleutian marine fish communities.

The pressure pulses and shock waves resulting from the nuclear detonations, particularly Cannikin, killed large numbers of several species of fish in offshore waters and changed marine habitat through uplifting of some rock benches. The effects were short term, however, with no detectable effects on the fish populations observed within a year after the Cannikin detonation. Because the total area of marine habitat affected by the tests was a small fraction of the total habitat around the island, the overall effect of the tests on the Amchitka Island marine ecosystem was considered temporary and insignificant.

\section{Aquatic Ecology (Valdez et al., 1977)}

The freshwater ponds and streams on Amchitka Island support few species of vertebrates and invertebrates. However, these waters do support six species of freshwater fish, including pink and silver salmon, which use the streams for spawning.

The Milrow and Cannikin detonations significantly affected ponds and streams within about 2 kilometers $(\mathrm{km})$ of SGZ at each site. Ponds were drained by fissuring or tilting, and stream channels were altered. Local fish populations were adversely impacted by terrain alterations and 
pressure waves generated by the detonations. Habitat alterations were not permanent. Fish populations fully recovered within five years of each test.

Preparations for the nuclear tests also had deleterious effects on the freshwater vertebrates and invertebrates. Drilling mud released and/or spilled into streams and ponds smothered the macroinvertebrates, which in turn depressed fish populations because of the absence of food organisms. The populations have recovered, and there are no known lasting impacts from the mud.

\section{Avifaunal Investigations (White et al., 1977)}

Bird populations on and near Amchitka Island were studied between 1967 and 1973 to determine species composition, ecological distribution, density, productivity, and seasonal movements. A total of 131 species were recorded, and evidence of breeding for 28 species was obtained.

The investigators predicted that the impacts of the Milrow and Cannikin nuclear testing could include habitat and nest-site destruction, destruction of birds, and accidental release of radionuclides. These predictions led to two recommendations regarding conduct of the tests. The first recommendation was to not conduct the tests during the height of the breeding season, when the greatest number of birds would be affected. The second was to conduct the tests during the winter months (November to February) to eliminate possible radionuclide transport by fall migrants and birds resident on Amchitka during the summer.

No actual direct effects of the Milrow test were detected in any bird populations. The immediate, actual results of the Cannikin test, however, were 15 test-related bird deaths, the loss of two peregrine falcon eyries that involved only one pair of falcons, additional damage to a falcon eyrie originally damaged by Milrow, the loss of six bald eagle nests, and damage to one eagle nest. The long-term effects of the tests could not be assessed at the time of the study, but a baseline of data was established for future studies.

\subsubsection{Tritium Sampling}

Tritium activity has been monitored in surface water and shallow groundwater on Amchitka Island from 1965 to the present under various programs (see Section 1.3.) Following the Long Shot detonation, anomalous concentrations of tritium were found in the vicinity of SGZ 27 days after the 
original test (Castagnola, 1969). The main activity front of radioactive gases reached the surface roughly six months or more after the Long Shot detonation. At least three and one-half years after the Long Shot test, anomalous concentrations of tritium in water existed in several surface waters in the vicinity of Long Shot SGZ, reaching a maximum observed concentration of about 5,000 tritium units (approximately 16,000 picocuries per liter [pCi/L]) in September 1966.

The drinking water standard for tritium is $20,000 \mathrm{pCi} / \mathrm{L}$. Tritium levels in some of the groundwater and surface water samples collected by the U.S. Environmental Protection Agency (EPA) in 1997 (Faller and Farmer, 1998) remain above background levels but well below the current safe drinking water levels. At locations around the SGZ, tritium concentrations continue to decrease faster than would be expected from tritium decay alone, indicating that dilution is also an important factor. Dasher et al. (2000) noted that tritium measurements taken since the Long Shot detonation indicate that radioactive gases escaped to the near surface shortly after the detonation but do not indicate long-term movement from the contaminated groundwater to the Long Shot SGZ surface environment.

In addition to the fact that tritium concentrations are declining faster than the rate of decay alone, hydrologic measurements at Amchitka indicate a downward flow for recharge water to a freshwater/saline water zone where movement occurs laterally. With the exception of a brief pathway from Long Shot immediately after the test that has since been flushed out, the results of hydrological tests indicate that there is no complete exposure pathway from the subsurface radionuclide source areas beneath the island to the shallow groundwater beneath or to surface water on the island (Claassen, 1978; Fenske, 1972a; Wheatcraft, 1995).

\subsubsection{Investigation of Radionuclides in Amchitka Island, Alaska Ecosystems (Dasher et al., 2004)}

In 1996, the Greenpeace organization reported that radionuclides associated with the three Amchitka Island underground nuclear test sites were leaking into the surface environments on the island. This report was based on limited sampling and analysis of selected biota on the island. In response to this report, radioecological studies of Amchitka freshwater and marine environments were conducted in 1997 and 1998 under the auspices of the Amchitka Technical Advisory Group, which consisted of representatives from the Alaska Department of Environmental Conservation, the DOE, the EPA, the 
USFWS, University of Alaska-Fairbanks, Aleutian/Pribilof Islands Association, Inc. (APIA), and other stakeholders.

Sampling transects of varying lengths were established on stream courses in four drainages, three associated with the underground test sites and a single reference location $8 \mathrm{~km}$ upgradient from each major test location. Four biota sampling sites were designated within each stream transect, and representative plant and sediment samples were collected at each. Marine transects for sampling marine algae were located at the outfalls of the streams. Sediment samples were obtained at each sampling location. In 1998, the same four stream drainages were resampled as well as four additional drainages on Amchitka. Three new stream transects on nearby Adak Island and at Cold Bay on the Alaska Peninsula were also added to the 1998 survey. In addition, 76 upland soil cores (100 square centimeters) and 34 lichen samples (0.25 square meters) were collected at 11 locations on Amchitka and at three sites each on Adak Island and at Cold Bay. All samples were analyzed for gamma- and alpha-emitters by conventional radioanalytical methods at three different laboratories. In addition, plutonium (Pu)-240 and $\mathrm{Pu}-239$ ratios were determined by thermal ionization mass spectrometry, and low-level tritium enrichment analyses were performed on selected surface water and precipitation samples.

Analytical results were comparable between the 1997 and 1998 surveys and the various laboratories, and concluded that worldwide fallout was the major source of radionuclides in surface environments of Amchitka Island. No indications were found suggesting "leakage” of radionuclides from the deep underground test cavity sources to the surface environment.

\subsubsection{Long-Term Hydrologic Monitoring Program}

A long-term hydrologic monitoring network was established on Amchitka Island in 1967 to document the effect of the underground nuclear testing on the island LTHM ceased in 2001 and the wells were either plugged or abandoned. Before 1972, ground and surface water sampling at the NTS and off-site areas, including Amchitka Island, was conducted by the U.S. Public Health Service, the U.S. Geological Survey, the AEC, and various contractor organizations. In 1972, all of the water sampling programs were combined under the Long-Term Hydrologic Monitoring Program, which is funded by NNSA/NSO and operated by the EPA Radiation and Indoor Environments National Laboratory in Las Vegas. 
Previous monitoring at Amchitka Island consisted of sampling and analyzing surface and groundwater samples on a biannual basis during odd years from the Long Shot, Milrow, and Cannikin test sites and from other locations on the island designated as background. (Sampling was not conducted in 1995, however, due to budget restrictions.) See Table 1-3 for a list of groundwater wells and the sampling depths for each. Tritium and gamma-spectral analyses were routinely performed, and new water sources were also initially analyzed for Sr-89 and Sr-90, radium-226, Pu-238 and $\mathrm{Pu}-239$, and uranium isotopes. Sampling required approximately two weeks per year, and about 40 samples were analyzed per year.

Table 1-3

Groundwater Wells and Sampling Depths

(Page 1 of 2)

\begin{tabular}{||c|c|c|c||}
\hline Site & Well & Depth & Sample Depth \\
\hline \hline Milrow & $\mathrm{W}-2$ & $1.0 \mathrm{ft}$ & $1.0 \mathrm{ft}$ \\
\hline Milrow & $\mathrm{W}-3$ & $3.7 \mathrm{ft}$ & $3.0 \mathrm{ft}$ \\
\hline Milrow & $\mathrm{W}-4$ & $<10 \mathrm{ft}$ & $2.5 \mathrm{ft}$ \\
\hline Milrow & $\mathrm{W}-5$ & $3.0 \mathrm{ft}$ & $2.8 \mathrm{ft}$ \\
\hline Milrow & $\mathrm{W}-6$ & $3.5 \mathrm{ft}$ & $3.1 \mathrm{ft}$ \\
\hline Milrow & $\mathrm{W}-7$ & $2.4 \mathrm{ft}$ & $2.4 \mathrm{ft}$ \\
\hline Milrow & $\mathrm{W}-8$ & $5.1 \mathrm{ft}$ & $5.1 \mathrm{ft}$ \\
\hline Milrow & $\mathrm{W}-9$ & $<10 \mathrm{ft}$ & $<10 \mathrm{ft}$ \\
\hline Milrow & $\mathrm{W}-10$ & $6.7 \mathrm{ft}$ & $6.0 \mathrm{ft}$ \\
\hline Milrow & $\mathrm{W}-11$ & $4.8 \mathrm{ft}$ & $4.0 \mathrm{ft}$ \\
\hline Milrow & $\mathrm{W}-12$ & $<10 \mathrm{ft}$ & $<10 \mathrm{ft}$ \\
\hline Milrow & $\mathrm{W}-13$ & $3.4 \mathrm{ft}$ & $3.4 \mathrm{ft}$ \\
\hline Milrow & $\mathrm{W}-14$ & $<10 \mathrm{ft}$ & $<10 \mathrm{ft}$ \\
\hline Milrow & $\mathrm{W}-15$ & $3.7 \mathrm{ft}$ & $3.0 \mathrm{ft}$ \\
\hline Milrow & $\mathrm{W}-16$ & $<10 \mathrm{ft}$ & $<10 \mathrm{ft}$ \\
\hline Milrow & $\mathrm{W}-17$ & $<10 \mathrm{ft}$ & $<10 \mathrm{ft}$ \\
\hline Milrow & $\mathrm{W}-18$ & $1.7 \mathrm{ft}$ & $1.7 \mathrm{ft}$ \\
\hline Milrow & $\mathrm{W}-19$ & $3.0 \mathrm{ft}$ & $3.0 \mathrm{ft}$ \\
\hline Long Shot & $\mathrm{WL}-1$ & $8.2 \mathrm{ft}$ & $5.5 \mathrm{ft}$ \\
\hline Long Shot & $\mathrm{WL}-2$ & $11.5 \mathrm{ft}$ & $10.0 \mathrm{ft}$ \\
\hline & & & \\
\hline
\end{tabular}


Table 1-3

\section{Groundwater Wells and Sampling Depths}

(Page 2 of 2)

\begin{tabular}{||c|c|c|c||}
\hline Site & Well & Depth & Sample Depth \\
\hline \hline Long Shot & GZ-1 & $100.0 \mathrm{ft}$ & $90.0 \mathrm{ft}$ \\
\hline Long Shot & GZ-2 & $50.0 \mathrm{ft}$ & $40.0 \mathrm{ft}$ \\
\hline Long Shot & EPA-1 & $25.5 \mathrm{ft}$ & $20.5 \mathrm{ft}$ \\
\hline Cannikin & HTH-3 & $152 \mathrm{ft}$ & $140 \mathrm{ft}$ \\
\hline
\end{tabular}

Since long-term hydrologic monitoring commenced on Amchitka, no significant concentrations of radionuclides attributable to the three underground test sites have been observed, with the exception of tritium from the Long Shot site (see Section 1.3.2). Concentrations of tritium at Long Shot have been steadily declining, however, and are below the safe drinking water standard. Monitoring under the Long-Term Hydrologic Monitoring Program last occurred in 2001.

\subsubsection{Groundwater Modeling}

The purpose of the 2002 groundwater modeling effort (NNSA/NV, 2002) was to provide information needed to conduct a human-health risk assessment of the potential hazard posed by the three underground nuclear tests on Amchitka Island. The modeling focused on subsurface transport of radionuclides released from the underground detonation cavities and their movement through the groundwater system to the point they seep out of the ocean floor into the marine environment.

Conceptual models for flow and transport for the tests were developed. A multiparameter uncertainty analysis was performed to address uncertainty in the supporting data, and separate sensitivity analyses were evaluated for specific conceptual uncertainties. The final modeling assumes that groundwater moves predominantly through fractures in the rock and considers multiple realizations of the flow field by drawing values of hydraulic conductivity, recharge, and porosity from their distributions. An additional separate sensitivity case was also presented addressing uncertainty in the matrix diffusion process.

The final model calibrations depict a deeper transition zone on the Bering Sea side of the island, as compared to the Pacific side. Transport results indicate that radionuclide movement at Long Shot is much faster than at Milrow and Cannikin. This faster rate is due to the location of the Long Shot 
cavity being shallow as compared to the other two tests. Long Shot is above the transition zone in all realizations, whereas Milrow and Cannikin tend to be within or below the transition zone. Below the transition zone, the flowpath toward the seafloor is lengthened and groundwater velocities are much slower. The arrival time of the peaks of mass flux and concentration for tritium was on the order of 20 to 30 years for Long Shot and 100 to 125 years for Milrow and Cannikin. This led to higher mass fluxes and concentrations breaking through at Long Shot than at Cannikin or Milrow, particularly due to the process of radioactive decay reducing mass as time proceeds.

The groundwater model results included a mean (expected) value and a standard deviation (measure of uncertainty). The standard deviation was large as a result of uncertainties in exact parameter values and their variability in the subsurface. The most significant uncertain parameter was found to be the porosity assigned to the fracture system. Uncertainty in the transition zone location also led to large variation in transport results from one realization to the next. The Consortium for Risk Evaluation with Stakeholder Participation (CRESP) independent science study (see Section 2.2 summary) provided new data regarding both porosity and the location of the transition zone. These data, along with new bathymetric profiles, were used to verify the Amchitka groundwater models, revise and update the model parameter distributions, and reduce uncertainty in the model results (CRESP, 2005).

Through a series of analyses, it was found that the new data provided by CRESP were consistent with the conceptual framework and range of parameter values used in the 2002 groundwater flow and transport model. The 2002 model was verified through a number of components. First, the high-resolution bathymetric data obtained by CRESP (2005) closely matched the profiles used in the models. Second, the posterior distributions for recharge, hydraulic conductivity, and their ratio (all constrained by the transition zone location information from CRESP), are encompassed within the original prior distributions used in the 2002 model, verifying that the original distributions were wide enough to include the new data. Third, the updated flow solution results in an ensemble mean matching the head and chemistry data within +/- one standard deviation of the original models. When the new data provided better control on parameter ranges, the wide uncertain range was trimmed from both sides, resulting in a new set of possible solutions encompassed within the original set of possible solutions. Though the CRESP data indicate a deeper transition zone at Milrow than indicated by site 
chemistry data, the possibility of a deeper transition zone was accounted for in the 2002 model by the wide range of recharge and hydraulic conductivity considered.

After updating the models with the new CRESP data, the resulting groundwater fluxes had the same distribution as the original model. A dramatic reduction in uncertainty was achieved by conditioning on all available data sets. The parameter distributions cover a much narrower range than originally used in the 2002 model. Using the new porosity profiles from CRESP (2005) results in very slow flow velocities, orders of magnitude slower than the velocities produced by the 2002 model. With the new porosities, radionuclides require thousands of years to reach the seafloor. No breakthrough resulted for any of the three sites within the 2000-year model timeframe in the updated model, despite ignoring all retardation mechanisms (sorption, radionuclide trapping in glass, matrix diffusion, and radioactive decay). In the 2002 model, the standard deviation of mass flux was larger than the mean, implying that the lower limit for radionuclide mass flux was essentially zero. This value is now indicated by the CRESP data, and was included in the possibilities presented by Hassan et al. (2002).

\subsection{Regulations}

Neither Amchitka Island nor the three test sites on the island are listed on the National Priorities List, and they are not subject to the Comprehensive Environmental Response, Compensation, and Liability Act (CERCLA) or the Resource Conservation and Recovery Act. Because they are not CERCLA sites, CERCLA regulations do not directly apply. However, these regulations are being used as guidance during the completion of these sites.

It is DOE's objective to conduct its completion activities at Amchitka Island so that radiation exposures to members of the public are maintained within the limits established by the DOE Order 5400.5, "Radiation Protection of the Public and the Environment” (DOE, 1993), and to control radioactive contamination through the management of real and personal property. It is also DOE's objective to protect the environment from radioactive contamination to the extent practicable. 


\subsection{Site Completion Justification}

Numerous investigations have been conducted on Amchitka Island to document the existing island environment as well as to assess the impact of the underground nuclear tests to environments on and surrounding the island. These investigations are listed in Table 1-3 of this report, and certain of these investigations are discussed in detail within Section 1.3. These investigations, in particular the 2002 groundwater modeling and the Consortium for Risk Evaluation with Stakeholder Participation (CRESP) study, indicate that there is no complete exposure pathway from the subsurface radionuclide source areas beneath the island to the shallow groundwater beneath or to surface water on the island and provide the basis for completion of the Amchitka site surface cleanup. A conceptual model of flow and transport for Amchitka Island has been developed based on the results of these investigations and is shown in Figure 2-1.

\section{$2.1 \quad$ Groundwater Modeling}

The purpose of the 2002 groundwater modeling effort (NNSA/NV, 2002), as described in detail in Section 1.3.5 of this report, was to provide information needed to assess the potential hazard posed by the three underground nuclear tests on Amchitka Island. The modeling focused on subsurface transport of radionuclides released from the underground detonation cavities and their movement through the groundwater system to the point they seep out of the ocean floor into the marine environment. The results of the modeling indicate that it takes thousands of years for radionuclides to reach the seafloor, and no breakthrough of radionuclides is estimated for any of the three sites within the 2000-year model timeframe.

\subsection{Independent Science Study}

The CRESP study was an independent scientific investigation of the hazards associated with the subsurface nuclear testing performed on Amchitka Island. The investigation was intended to address concerns from stakeholders regarding possible human health and ecological effects of this testing, and to provide current and relevant data to help DOE move toward long-term surveillance and maintenance of the site. 


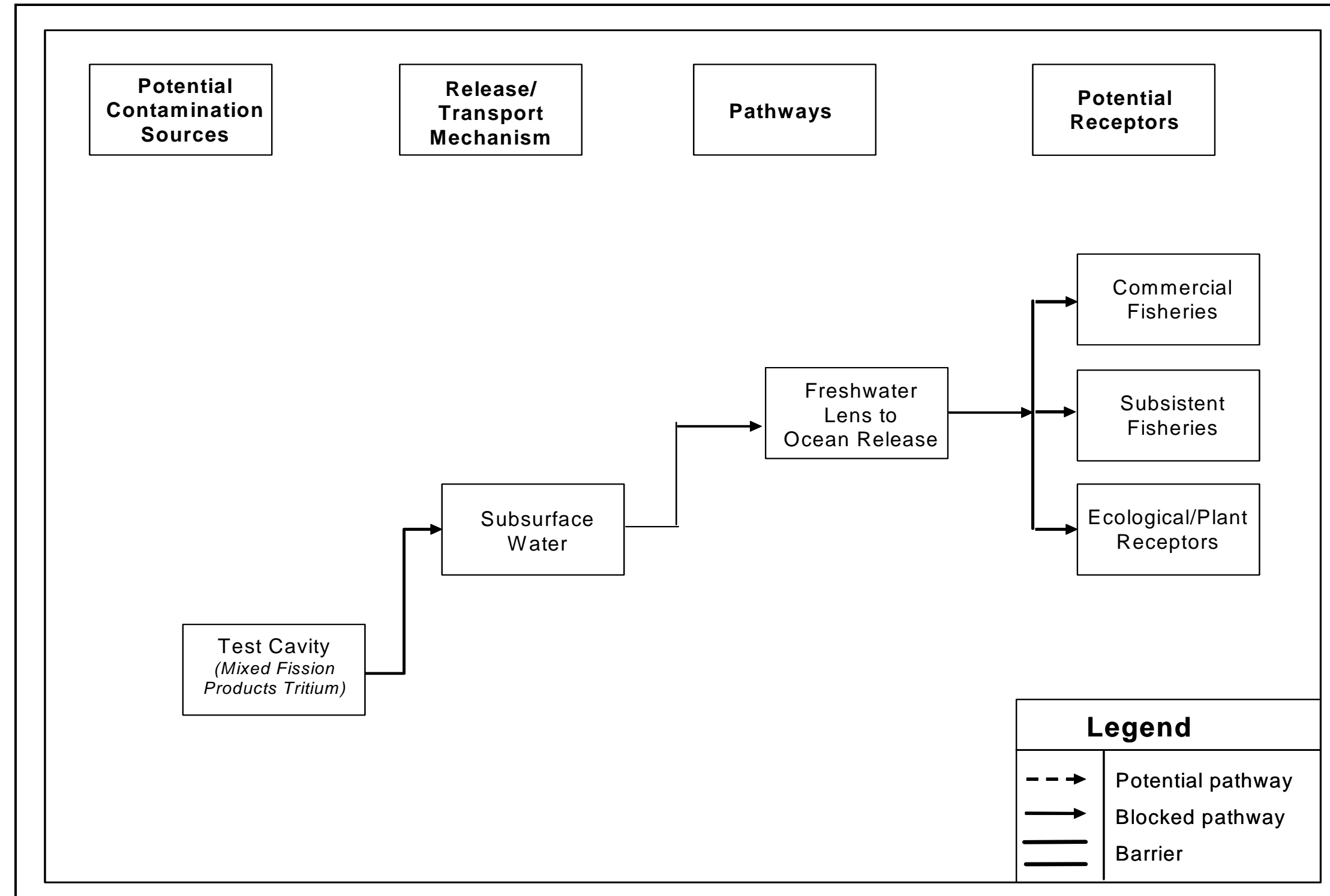

Figure 2-1

Conceptual Model

Uncontrolled When Printed 
The results of the CRESP study were released in the Final Report of the Consortium for Risk Evaluation with Stakeholder Participation, Amchitka Independent Science Assessment: Biological and Geophysical Aspects of Potential Radionuclide Exposure in the Amchitka Marine Environment, (CRESP, 2005).

Some of the conclusions from the CRESP studies are:

- None of the marine organisms tested had radiation levels that would pose a threat to humans, and all results are well below published human health food safety standards and guidelines.

- The levels of radionuclides measured in biota are within the range found in biota from other marine environments in the Northern Hemisphere and are far below levels found in known contaminated marine areas, such as the Irish Sea. They are also below any levels known to impact organisms or ecosystems.

- The levels of europium-152, cobalt-60, Sr-90, iodine-129, and technetium-99 were all or almost all below the minimum detection activity (MDA) levels, which, in turn, were 10 times or more lower than food safety standards and guidelines. Several organisms had accumulated americium-241 to just above the MDA, but there was no pattern with respect to species, trophic level, or island. Cesium (Cs)-137, plutonium, and uranium isotopes were found more widespread.

- For most radionuclides, there were no significant differences between Amchitka and Kiska (the reference site) in either the number of values above the MDAs or in the average concentrations.

- There were differences among species in the levels of some radionuclides: high trophic level predators had higher Cs-137 levels than others lower on the food chain, and primary producers (algae) had significantly higher levels of Pu-239 and Pu-240 than all others. These findings are consistent with the findings in other scientific studies in that they indicate that fish bioaccumulate cesium from the food chain and algae takes up $\mathrm{Pu}$ at a rate many times higher than do other biota.

- Substantial localized discharge of freshwater through the ocean floor within the study area was not indicated based on ocean floor salinity measurements. Thus, no specific preferential pathway (i.e., large freshwater flow through geologic faults) for contaminant migration along with fresh groundwater from the tests was found.

- Geophysical investigations indicate that all three tests were within the transition zone between fresh and salt groundwater, and that greater subsurface pore volume was present than assumed by earlier studies, suggesting very long travel times for any contaminant migration from the tests to the marine environment. 
- The CRESP expedition did not find either geophysical or biological evidence of recent or current radionuclide migration into the marine environment from the Amchitka nuclear tests. The nature and spatial pattern of detectable radionuclides, do not suggest that they are attributable to the Amchitka nuclear tests.

As stated in the executive summary from the final report: “Overall, our geophysical and biological analyses did not find evidence of risk from radionuclides from the consumption of marine foods, nor indication of any current radionuclide contaminated migration into the marine environment from the Amchitka nuclear tests. Our data are useful in reducing the uncertainties in the groundwater models and risk assessments, to indicate that there are species at multiple trophic levels that would be at risk if there were contaminated seepage from the tests, and to provide insights for selecting bioindicators for a monitoring plan for the future and a baseline useful for comparison in any future biomonitoring.” (CRESP, 2005). 


\subsection{Completion Recommendation and Strategy}

As discussed previously, monitoring, modeling and assessment of radionuclide transport from the test cavities to the surface and marine environments of Amchitka Island have found no current seepage into these areas. Additionally, biomonitoring results indicate very low levels of radionuclides in some marine organisms, levels significantly below any health concern and at similar levels found in other marine environments where no known releases or sources of radionuclides exist. Although radionuclides remain in the deep subsurface of the island environment, there is no complete pathway from the subsurface to surface environment, and no technically feasible method exists to contain or remove them. Based on these study results, in particular those of the groundwater modeling and the CRESP study, a recommendation of No Further Remedial Action Planned with Long-Term Surveillance and Maintenance is made for the Amchitka Site.

\subsection{Recommendations}

\subsubsection{Recommended Alternative}

The recommended remedy for the Amchitka Site is No Further Remedial Action Planned with Long-Term Surveillance and Maintenance.

\subsection{Institutional Controls}

There are several institutional controls currently implemented at Amchitka Island with the intent to protect human health and the environment from surface and subsurface areas:

- The Amchitka Site is located in a designated wilderness portion of the AMNWR under the jurisdiction of the USFWS. Administrative control is achieved by limiting the land use to recreation, use as a wildlife refuge, and subsistence use by local native inhabitants. The DoD retains the right to use the island, if determined necessary, for national defense purposes.

- The USFWS is the landowner and maintains all mineral rights for the island.

- A bronze plaque was mounted onto a concrete monument and placed at SGZ for each of the three events. Each plaque explained the event and restrictions that apply to the nearby area. The event description plaque at Milrow is missing, but the restrictions plaque is still intact. A steel "hole-marker" post with a nameplate, extending about $4 \mathrm{ft}$ above the land surface, was 
installed at each of the plugged holes. The restrictions on the plaques, mounted onto the concrete monuments at each event site, read as follows:

\section{Long Shot:}

"No excavation, drilling, and/or removal of materials is permitted, without U.S. Government approval, between ground surface and 914 meters (3,000 feet) below mean sea level and out to a horizontal distance of 305 meters (1,000 feet) from GZ”

\section{Milrow:}

"No excavation, drilling, and/or removal of materials is permitted, without U.S. Government approval, between ground surface and 1,524 meters (5,000 feet) below mean sea level and out to a horizontal distance of 305 meters (1,000 feet) from GZ”

\section{Cannikin:}

"No excavation, drilling, and/or removal of materials is permitted, without U.S. Government approval, between ground surface and 1,890 meters (6,200 feet) below mean sea level and out to a horizontal distance of 914 meters (3,000 feet) from GZ”

Additional institutional controls restricting subsurface activities may be established under the LTSMP in coordination with the landowner and stakeholders.

\subsection{Long-Term Surveillance and Maintenance}

With the planned completion of the Amchitka Site characterization and implementation of the chosen remedial action, the Amchitka Site will move from a characterization and remedial action phase to a long-term surveillance and maintenance phase. To align this change with DOE's operational structure, the DOE is transitioning the operation of the site from the DOE's Office of Environmental Management (EM) to the DOE's Office of Legacy Management (LM). The LM's mission is to manage the DOE's post-closure responsibilities and ensure the future protection of human health and the environment. The LM is responsible in perpetuity for implementing long-term surveillance and maintenance, which includes all necessary monitoring and any future response actions. 


\subsection{Governing Documents}

The purpose of this report is to document EM's efforts to date and to serve as a mechanism to obtain regulator concurrence on the completion of the site. Upon acceptance of this Completion Report, EM and LM will work together to transition the site to LM (October 1, 2006). Future long-term surveillance and maintenance actions will be governed by an LTSMP. The LTSMP is being developed with LM as the lead author with support from EM, and reviews by regulators and stakeholders.

\subsubsection{Long-Term Surveillance and Maintenance Plan Requirements}

The LTSMP and subsequent related documents will provide the details of the monitoring strategy including species to be sampled, frequency of collection, method of collection, and radionuclides analyzed. The primary purpose of the plan is to ensure protection of human health and the environment through an effective monitoring process whereby unanticipated risk would be identified in a timely manner allowing corrective action. The identification of risk from other contaminants in the environment from non-DOE activities is not part of the long-term surveillance and maintenance program.

Based on the investigations conducted to date and documented in this report, the regular periodic monitoring strategy will include foodstuff and biota monitoring. Groundwater and surface water monitoring on a regular basis may be pursued based on the results of the groundwater model and independent science study. Biota and foodstuff monitoring directly monitor the completed risk pathway and serve as the most effective measure of human health and ecological risk. The LTSMP will include a Contingency Analysis of extreme events (such as earthquakes or volcanoes) that will identify potential conditions, probable consequences, and contingency actions.

The LTSMP shall determine the target biota to be monitored on a regular periodic basis using, but not limited to, the following criteria:

- Presence in the risk pathway - Species should be part of the food web or indicators for a part of the food web that acts as the completed risk pathway. Preference will be given to species that are part of the completed risk pathway, but indicator species will also be considered. 
- Bioaccumulation potential - Species with high potential for bioaccumulation provide early indication of contamination in the food web.

- Trophic level - Species from various parts of the food web should be sampled to allow for increased confidence in detection of contamination in the food web.

- Species availability - Species should be available at the site, collection of the species should not adversely impact the species population, and the collection should not be overly difficult nor expensive.

The LTSMP will define the monitoring frequency and analysis methods for the biota sampling. The sampling frequency and analysis methods shall be designed to identify contamination before it presents a human health risk. Care should be taken to design a system that can be implemented in a cost-efficient manner.

The LTSMP will consider the use of faster-moving radionuclides present at the site as indicators of contaminant migration. Regular monitoring for slow-moving radionuclides (those whose movement is retarded by reactions with rock and sediment) would be less effective. The potential for bioaccumulation will be considered in selection of radionuclides for monitoring. The analytical suite will be expanded in case migration of indicator radionuclides is detected.

The LTSMP will favor the use of local hunters/fishermen, as well as commercial catch operators, as collection methods for the biota monitoring program, provided the program goals can be effectively met by those methods. Additionally, specimens may be collected during the surface cap inspection site visits. There are a variety of organizations that are well suited to the monitoring task that could be used for efficient, representative biota sampling, including the University of Alaska-Fairbanks, Aleutian Pribilof Islands Association, U.S. Fish and Wildlife Service, and National Oceanographic and Atmospheric Administration.

The LTSMP and subsequent related documents will provide a strategy to retain and archive biota samples. The plan will evaluate the value of this baseline information for comparison to future sampling and make recommendations on the disposition of the samples. 


\subsection{Public Participation}

Several groups and entities have an interest in Amchitka Island, the remediation efforts there, and future activities on and use of the island. The primary Amchitka Site stakeholders include:

- Alaska Department of Environmental Conservation

- U.S. Fish and Wildlife Service, Alaska Maritime Wildlife Refuge

- U.S. Army Corps of Engineers, Alaska District

- U.S. Navy

- Aleutian/Pribilof Islands Association, Inc.

- Alaska Community Action on Toxics

Public participation has been a key aspect to the remediation efforts on Amchitka. Listed below are the public meetings that have been held to date regarding DOE's involvement with Amchitka:

- November 18-19, 1996: Anchorage, Alaska - Meeting with multiagency/stakeholder representatives

- December 16-17, 1996: Anchorage, Alaska - Agency and stakeholder issues/proposed investigative activities

- May 1, 2001: Anchorage, Alaska - APIA Board of Directors Meeting

- May 2, 2001: Anchorage, Alaska - Public Information Meeting

- December 4, 2001: Anchorage, Alaska - Public Information Meeting and Open House

- December 5, 2001: Anchorage, Alaska - APIA Presentation

- December 4, 2002: Anchorage, Alaska - Public Information Meeting

- May 13, 2003: Dutch Harbor, Alaska - Public Information Meeting

- May 14, 2003: Anchorage, Alaska - Public Information Meeting

Although a public reading room is not available, site documents are archived and can be accessed at the following location:

Aleutian/Pribilof Islands Association, Inc.

201 East $3^{\text {rd }}$ Avenue

Anchorage, AK 99501-2455

www.apiai.com 
Legacy Management has the ultimate responsibility for maintaining site records in accordance with the federal disposition schedule. Laboratory analytical data are maintained at the Denver Federal Records Center in Denver, Colorado. All other site documentation (e.g., waste records, correspondence, field data) and library material are maintained at the Legacy Management office in Grand Junction, Colorado. 


\subsection{References}

Anderson, R.E. 1971. Tectonic Setting of Amchitka Island, Alaska. U.S. Geological Survey Report USGS-474-75, Rev. 1.

Ballance, W.C., 1970a. Hydraulic testing of hole UAe-7h, Amchitka Island, Alaska. U.S. Geological Survey, Report USGS-474-84, 31p.

Ballance, W.C., 1970b. Hydraulic tests in hole UA-1 and water inflow into an underground chamber, Amchitka Island, Alaska. U.S. Geological Survey, Report USGS-474-72, 54p.

Ballance, W.C., 1972a. Hydraulic tests in drill hole UAe-1, Amchitka Island, Alaska.

U.S. Geological Survey, Report USGS-474-102, 32p.

Ballance, W.C., 1972b. Hydraulic tests in hole UAe-6h, Amchitka Island, Alaska. U.S. Geological Survey, Report USGS-474-104, 27p.

Ballance, W.C., 1973a. Hydraulic tests in hole UAe-2, Amchitka Island, Alaska. U.S.Geological Survey, Report USGS-474-103, 59p.

Ballance, W.C., 1973b. Hydraulic tests in hole UAe-3, Amchitka Island, Alaska. U.S. Geological Survey, Report USGS-474-26, Rev.1, 30p.

Ballance, W.C. and G.A. Dinwiddie, 1972. Hydraulic testing of hole UA-1-HTH-1, Amchitka Island, Alaska. U.S. Geological Survey, Report USGS-474-144, 27p.

Bath, G.D., C.H. Miller, and W.D. Quinlivan. 1971. Interpretation of a Gravity Survey of Amchitka Island, Alaska. U.S. Geological Survey Report USGS-474-93 (Amchitka-24).

Bath G.D., W.J. Carr, L.M. Gard Jr., and W.D. Quinlivan. 1972. Interpretation of an Aeromagnetic Survey of the Amchitka Island Area, Alaska. U.S. Geological Survey Professional Paper 707.

Beetem, W.A., R.A. Young, C.L. Washington, and L.J. Schroder. 1971. Chemical Analyses of Water Samples Collected on Amchitka Island, Alaska. U.S. Geological Survey Report USGS-474-135 (Amchitka-29).

CRESP, see Consortium for Risk Evaluation with Stakeholder Participation.

Carr, W.J., and W.D. Quinlivan. 1969. Progress Report on the Geology of Amchitka Island, Alaska. U.S. Geological Survey, Report USGS-474-44 (Amchitka-5) (revised).

Carr, W.J., L.M. Gard Jr., and W.D. Quinlivan. 1969. Geologic Reconnaissance of Amchitka Island, Alaska, December 1966. U.S. Geological Survey, Report USGS-474-42 (Amchitka-3) (distributed in 1970 and reprinted in 1971). 
Carr, W.J., L.M. Gard, G.D. Bath, and D.L. Healey. 1971. "Earth-Science Studies of a Nuclear Test Area in the Western Aleutian Islands, Alaska: An Interim Summary of Results,” in Geological Society of America Bulletin, 82:699-706.

Castagnola, D.C. 1969. Tritium Anomalies on Amchitka Island, Alaska, Part I: Atomic Energy Commission. Report NVO-1229-113.

Claassen, H.C. 1978. Hydrologic Processes and Radionuclide Distribution in a Cavity and Chimney Produced by the Cannikin Nuclear Explosion, Amchitka Island, Alaska. Geological Survey Professional Paper, 712-D, U.S. Geological Survey, Washington, DC, p. 28.

Consortium for Risk Evaluation with Stakeholder Participation. 2005. Final Report of the Consortium for Risk Evaluation with Stakeholder Participation, Amchitka Independent Science Assessment: Biological and Geophysical Aspects of Potential Radionuclide Exposure in the Amchitka Marine Environment. Piscataway, NJ.

Dasher, D.H., W.C. Hanson, S.M. Read, S.H. Faller, D.E. Farmer, D.W. Efurd, J.J. Kelley, and R.H. Patrick. 2004. Investigation of Radionuclides in Amchitka Island, Alaska Ecosystems, 1997-1998, draft article for review. Version \#14 (03-16-01).

Dasher, D., W. Hanson, S. Read, S.H. Faller, D.E. Farmer, W. Efurd, J. Kelley, and R. Patrick. 2000. "An Assessment of the Reported Leakage of Anthropogenic Radionuclides from the Underground Nuclear Tests at Amchitka Island, Alaska, USA to the Surface Environment,” in Journal of Environmental Radioactivity 60 (2002) 165-187.

DOE, see U.S. Department of Energy.

Dudley, Jr., W.W., W.C. Balance, and V.M. Glanzman, 1977. “Hydrology,” in Merritt, M.L. and R.G. Fuller, editors, 1977. The environment of Amchitka Island, Alaska. Energy Research and Development Administration, Technical Information Center, pp.35-51p.

EPA, see U.S. Environmental Protection Agency.

Essington, E.H., P.R. Fenske, and W.E. Nork. 1970. Radioactivity in Water, Project Milrow. Teledyne Isotopes Report for the U.S. Atomic Energy Commission, Nevada Operations Office, NVO-1229-135.

Essington, E.H., E.J. Forslow, and D.C. Castagnola. 1971. An Interim Summary of Tritium Data for STS “A,” Amchitka Island, Alaska, July 1, 1969 through June 30, 1970. Teledyne Isotopes Report, NVO-1229-157.

Faller, S.H., and D. E. Farmer. 1998. Long-Term Hydrological Monitoring Program, Amchitka Alaska, EPA Report, EPA-402-R-98-002.

Federal Register. 1913. Executive Order 1733, "Establishment of the Aleutian Islands National Wildlife Refuge.” 3 March. Washington, DC. 
Fenske, P.R. 1972a. Event-Related Hydrology and Radionuclide Transport at the Cannikin Site, Amchitka Island, Alaska. U.S. Atomic Energy Commission, Nevada Operations Office, Report \# NVO-1253/1, p. 41.

Fenske, P.R. 1972b. Hydrology and Radionuclide Transport, Amchitka Island, Alaska. Desert Research Institute, Technical Report Series H-W, Hydrology and Water Resources Publication No. 12.

Freymueller, J., G. Hill, and J. Eichelberger. 2002. “Active Tectonics of Amchitka,” Oral Presentation for CRESP II Amchitka Island Long-term Stewardship Workshop, Winter 2002, Fairbanks, AK.

Fuller, R.G., and J.B. Kirkwood. 1977. “Ecological Consequences of Nuclear Testing,” in The Environment of Amchitka Island, Alaska. U.S. Energy Research and Development Administration Report TID-26712, pp. 627-649.

Gard Jr., L.M. 1972. Chemical Analyses of Igneous Rocks from Drill Holes and Outcrops, Amchitka Island, Alaska (including Working-Point Rocks of Long Shot, Milrow and Cannikin Events). U.S. Geological Survey, Report USGS-474-140.

Gard Jr., L.M., and W.E. Hale. 1964. "Geology and Hydrology of the Long Shot Site, Amchitka Island, Alaska.” U.S. Geological Survey, Technical Letter Long Shot-1.

Gates, O., G.D. Fraser, and G.L. Snyder. 1954. "Preliminary Report on the Geology of the Aleutian Islands,” in Science, v. 119, pp. 446-447.

Gonzalez, D.D. 1977. Hydraulic Effects of Underground Nuclear Explosions, Amchitka Island, Alaska, Ph.D. dissertation, Colorado State University, Fort Collins, CO.

Gonzalez, D.D., and L.E. Wollitz. 1972. "Hydrological Effects of the Cannikin Event,” in Bulletin of the Seismological Society of America, 62(6):1527-1542.

Hassan, A., K., Pohlmann, and J. Chapman. 2001. "Uncertainty Analysis of Radionuclide Transport in a Fractured Coastal Aquifer with Geothermal Effects,” in Transport in Porous Media, 43:107-136.

Hassan, A., K. Pohlmann, and J. Chapman, 2002. Modeling groundwater flow and transport of radionnuclides at Amchitka Island'ss underground nuclear tests: Milrow, Long Shot, and Cannikin. Desert Research Institute Division of Hydrologic Sciences Report No. 45172, DOE Nevada Operations Office Report DOE/NV/11508-51, 249p.

Hassan, A.E., J.B. Chapman, and K.F. Pohlmann. 2004. "Uncertainty Analysis of Seawater Intrusion and Implications for Radionuclide Transport at Amchitka Island's Underground Nuclear Tests," in Coastal Aquifer Management: Monitoring, Modeling, and Case Studies. Edited by A.H.-D. Cheng and D. Quazar, pp. 205-231. 
Lee, W.H. 1969a. Some Physical Properties of Rocks in Drill Hole UAe-2, Amchitka Island, Alaska. U.S. Geological Survey, Report USGS-474-5.

Lee, W.H. 1969b. Some Physical Properties of Rocks in Drill Hole UAe-1, Amchitka Island, Alaska. U.S. Geological Survey, Report USGS-474-48.

Lee, W.H. 1969c. Some Physical Properties of Rocks in Drill Hole UAe-3, Amchitka Island, Alaska. U.S. Geological Survey, Report USGS-474-6.

Lee, W.H. 1969d. Some Physical Properties of Rocks in Drill Hole UAe-6c, Amchitka Island, Alaska. U.S. Geological Survey, Report USGS-474-33.

Lee, W.H., and L.M. Gard, Jr. 1971. Summary of the Subsurface Geology of the Cannikin Site, Amchitka Island, Alaska. U.S. Geological Survey, Report USGS-474-132 (Amchitka 6-4).

Merritt, M.L. 1973. Physical and Biological Effects, Cannikin. U.S. Atomic Energy Commission, Nevada Operations Office, Las Vegas, Nevada, Report NVO-123.

Merritt, M.L., and R.G. Fuller. 1977. The Environment of Amchitka Island, Alaska. Albuquerque, NM.

Merritt, M.L., and R.G. Fuller. 1977. The Environment of Amchitka Island, Alaska. U.S. Energy Research and Development Administration Report TID-26712.

NCRP, see National Council on Radiation and Measurements.

NNSA/NSO, see U.S. Department of Energy, National Nuclear Security Administration Nevada Site Office.

NNSA/NV, see U.S. Department of Energy, National Nuclear Security Administration Nevada Operations Office.

National Council on Radiation Protection and Measurements. 1987. Ionizing Radiation Exposure of the Population of the United States. NCRP Report No. 93, Bethesda, MD.

Nork, W.E., J.V.A. Sharp, and C.L. Carnahan. 1965. Ground-water Safety Feasibility Project Long Shot. Hazleton-Nuclear Science Corporation, Palo Alto, CA.

Ohl, J.P. 1973. Bibliography of Published Reports by U.S. Geological Survey Personnel on the Geology and Hydrology of the Amchitka Supplemental Test Area, Aleutian Islands, Alaska, 1969-1972. U.S. Geological Survey Report USGS-474-164.

ONR, see Office of Naval Research.

Office of Naval Research. 1997. Radionuclides in the Arctic Seas from the Former Soviet Union: Potential Health and Ecological Risks. Livermore, CA. 
Pohlmann, K.F., A. Hassan, and J. Chapman. 2002. Modeling Density-Driven Flow and Radionuclide Transport at an Underground Nuclear Test: Uncertainty Analysis and Effect of Parameter Correlation. Water Resources Research, 38(5):10.1029/2001WR001047.

Seymour, A.H., and V.A. Nelson. 1977. "Radionuclides in Air, Water, and Biota,” in The Environment of Amchitka Island, Alaska. U.S. Energy Research and Development Administration Report TID-26712, pp.579-613.

Simenstad, C.A., J.S. Isakson, and R.E. Nakatani. 1977. “Marine Fish Communities,” in The Environment of Amchitka Island, Alaska. U.S. Energy Research and Development Administration Report TID-26712, pp. 451-492.

USC, see United States Code.

U.S. Army Corps of Engineers and U.S. Geological Survey. 1965. Project Long Shot Amchitka Island, Alaska, Geologic and Hydrologic Investigations (Phase I). Unnumbered report.

U.S. Atomic Energy Commission. 1967. Site-Selection Report, Supplemental Test Site Program, Amchitka Island. Prepared by Holmes and Narver for U.S. AEC (no document number).

United States Code. 1954. 42 United States Code 2011 et seq., The Atomic Energy Act of 1954, as amended. 30 August. Washington, DC: U.S. Government Printing Office.

U.S. Department of Energy. 1982. Long-Term Hydrologic Monitoring Program, Amchitka Island, Alaska. Nevada Operations Office Report NVO-242.

U.S. Department of Energy. 1988. Announced United States Nuclear Tests, July 1945 Through December 1987. Nevada Operations Office Report NVO-209.

U.S. Department of Energy. 1993. Order 5400.5: "Radiation Protection of the Public and the Environment,” Washington, DC.

U.S. Department of Energy, National Nuclear Security Administration Nevada Operations Office. 2002. Modeling Groundwater Flow and Transport of Radionuclides at Amchitka Island's Underground Nuclear Tests: Milrow, Long Shot, and Cannikin, Rev. 0, DOE/NV--11508-51, Las Vegas, NV.

U.S. Department of Energy, National Nuclear Security Administration Nevada Site Office. 2003. Amchitka Island Surface Closure Report, Rev. 1, DOE/NV--819, Las Vegas, NV.

U.S. Environmental Protection Agency. 1994. Estimating Radiogenic Cancer Risks, Publication EPA 402-R-93-076. Washington DC: Office of Radiation and Indoor Air. 
U.S. Environmental Protection Agency. 1998. Risk Assessment Guidance for Superfund: Volume 1, Human Health Evaluation Manual, Part D, Standardized Planning, Reporting, and Review of Superfund Risk Assessments, Publication 9285.7-01D. Washington, DC: Office of Emergency and Remedial Response.

U.S. Environmental Protection Agency. 2004. 40CFR300: National Oil and Hazardous Substances Pollution Contingency Plan. United States Government Printing Office, Washington, DC.

U.S. Geological Survey. 1970. Geologic and Hydrologic Effects of the Milrow Event, Amchitka Island, Aleutian Islands, Alaska. U.S. Geological Survey Report USGS-474-71 (Amchitka-20).

U.S. Geological Survey. 1972. Geologic and Hydrologic Effects of the Cannikin Underground Nuclear Explosion, Amchitka Island, Aleutian Islands, Alaska. U.S. Geological Survey Report USGS-474-148 (Amchitka-33).

Valdez, R.A., W.T. Helm, and J.M. Neuhold. 1977. “Aquatic Ecology” in The Environment of Amchitka Island, Alaska. U.S. Energy Research and Development Administration Report TID-26712, pp. 287-313.

von Huene, R., W.J. Carr, D. McManus, and M. Holmes. 1971. Marine Geophysical Study Around Amchitka Island, Western Aleutian Islands, Alaska. U.S. Geological Survey Report USGS-474-74 (Amchitka-22).

Wheatcraft, S.W. 1995. Sea Water Intrusion Model of Amchitka Island, Alaska. U.S. Department of Energy, Nevada Operations Office Report \# DOE/NV/10845-59.

White, C.M., F.S.L. Williamson, and W.B. Emison. 1977. “Avifaunal Investigations,” in The Environment of Amchitka Island, Alaska. U.S. Energy Research and Development Administration Report TID-26712, pp. 227-260. 


\section{Appendix A}

\section{ADEC and FWS Comment Responses for Amchitka Completion Report \\ (8 Pages)}




\section{NEVADA ENVIRONMENTAL RESTORATION PROJECT DOCUMENT REVIEW SHEET}

\begin{tabular}{|c|c|c|c|c|c|}
\hline \multicolumn{4}{|c|}{$\begin{array}{l}\text { 1. Document Title/Number Subsurface Completion Report for Amchitka } \\
\text { Underground Nuclear Test Sites Long Shot, Milrow, and Cannikin, dated } \\
\text { June, } 2006\end{array}$} & \multicolumn{2}{|l|}{ Document Date June, 2006} \\
\hline \multicolumn{4}{|c|}{ Revision Number 0} & \multicolumn{2}{|l|}{ Originator/Organization John Halverson } \\
\hline $\begin{array}{l}\text { 5. Respo } \\
\frac{\text { Sanders }}{7 . \quad \text { Revie }}\end{array}$ & \multicolumn{2}{|c|}{$\begin{array}{l}\text { Responsible NNSA/NSO ERP Subproject Mgr. John B. Jones, Pete } \\
\text { rs }\end{array}$} & 6. & Date Comments Due & $\underline{6}$ \\
\hline \multicolumn{3}{|c|}{ Reviewer/Organization/Phone No. John Halverson, ADEC } & 9. & \multicolumn{2}{|l|}{ Reviewer's Signature _ } \\
\hline $\begin{array}{l}10 . \\
\text { Comment } \\
\text { Number/ } \\
\text { Location }\end{array}$ & $\begin{array}{c}11 . \\
\text { Type }^{\mathrm{a}}\end{array}$ & 12. $\quad$ Comment & 13. & Comment Response & $\begin{array}{c}14 . \\
\text { Accept }\end{array}$ \\
\hline $\begin{array}{l}\text { 1. Exec } \\
\text { Summ; p. ES- } \\
1\end{array}$ & & $\begin{array}{l}\text { The third paragraph still includes a reference to } \\
\text { the screening level risk assessment, which should } \\
\text { be deleted. Also, DEC comment } \# 4 \text { on the prior } \\
\text { draft requested a statement be added noting there } \\
\text { are no feasible means to contain or remove } \\
\text { radionuclides in or around the shot cavities } \\
\text { beneath the site. The response to comments } \\
\text { states this was added to the } 4^{\text {th }} \text { paragraph, but the } \\
\text { text was not included in the document. }\end{array}$ & $\begin{array}{l}\text { Referenc } \\
\text { Statemer }\end{array}$ & leted & \\
\hline $\begin{array}{l}\text { 2. Section } \\
1.1 .2, \text { p. } 3\end{array}$ & & $\begin{array}{l}\text { It refers to the 1972-'73 site reclamation efforts. } \\
\text { DEC has a copy of the June } 1972 \text { Demob, } \\
\text { Restoration, and Monitoring Plan Directive } \\
\text { prepared by the Atomic Energy Commission. It } \\
\text { describes sites disturbed by AEC activates and } \\
\text { reclamation or restoration plans for each. } \\
\text { However, I was unable to locate a copy of any } \\
\text { report documenting what was actually done } \\
\text { during the reclamation efforts. Does DOE have } \\
\text { such a report that can be added to our files and } \\
\text { the public information repositories? Such a } \\
\text { report could provide valuable information on } \\
\text { disposal areas or wastes that may remain in place } \\
\text { and consideration for future land use planning. }\end{array}$ & $\begin{array}{l}\text { An AEC } \\
\text { Demobil } \\
\text { documen } \\
\text { www.ost } \\
\text { \&osti_id }\end{array}$ & $\begin{array}{l}\text { ioment titled "Summary Report Amchitka } \\
\text { ion and Restoration Activities" Dated June } 1974 \\
\text { Imber NVO-146 is available at: } \\
\text { v/bridge/product.biblio.jsp?query_id=1\&page=0 } \\
03684\end{array}$ & \\
\hline
\end{tabular}




\section{NEVADA ENVIRONMENTAL RESTORATION PROJECT \\ DOCUMENT REVIEW SHEET}

Document Title/Number

Revision Number

Reviewer/Organization

\begin{tabular}{|c|c|c|}
\hline 3. Table 1-1 & $\begin{array}{l}\text { a) The "12/2000" row still refers to USFW } \\
\text { conducting an EIS, which should be changed to } \\
\text { an Environmental Assessment (EA). }\end{array}$ & Change made \\
\hline & $\begin{array}{l}\text { b) The "Summer } 2001 \text { " row states, "no well } \\
\text { locations that require monitoring remain on site"; } \\
\text { the report should clarify the location and } \\
\text { construction details for wells that do remain, } \\
\text { regardless of whether they require monitoring. } \\
\text { Table } 1-2 \text { does identify two remaining wells, but } \\
\text { it is unclear if any others exist. }\end{array}$ & $\begin{array}{l}\text { Change to read: } \\
\text { " } 16 \text { wells were plugged and abandoned, } 6 \text { could not be found, } \\
2 \text { wells (GZ-1, GZ-2) were covered and locked, and } 1 \text { well } \\
\text { (UAe-7e/h) was left open as a possible future monitoring } \\
\text { well. The GZ-1, GZ-2, and UAe-7e/h wells were located } \\
\text { during the } 2006 \text { Mud Pit Cap Inspection and the above status } \\
\text { was verified. No other DOE wells exist on site and none are } \\
\text { being monitored. The U.S. Navy demolished and removed all } \\
\text { DoD buildings on the island." }\end{array}$ \\
\hline 4. Table 1-2 & $\begin{array}{l}\text { Thank you for providing additional details on the } \\
\text { various wells installed as part of the underground } \\
\text { testing program. Several of the descriptions of } \\
\text { the abandonment activity warrant clarification, as } \\
\text { follows: } \\
\text { a) Many of the activity descriptions conclude } \\
\text { with the statement, "Abandonment Complete" } \\
\text { but others do not; were additional steps planned } \\
\text { to complete abandonment on the other wells? }\end{array}$ & $\begin{array}{l}\text { Added "Abandonment Complete" statement to all wells that } \\
\text { were plugged and abandoned. }\end{array}$ \\
\hline
\end{tabular}

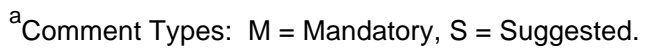

Return Document Review Sheets to NNSA/NSO Environmental Restoration Division, Attn: QAC, M/S 505.

LV9-19-06INDEP-ADEC comment responses 8-23 SN-014

Uncontrolled When Printed 


\section{NEVADA ENVIRONMENTAL RESTORATION PROJECT DOCUMENT REVIEW SHEET}

Document Title/Number

Revision Number

Reviewer/Organization

\begin{tabular}{|c|c|c|}
\hline & $\begin{array}{l}\text { b) Many of the activity descriptions partially } \\
\text { describe how the wells were decommissioned } \\
\text { and closed or are unclear. For example, wells } \\
\mathrm{OH}-6 \text { through } 9 \text { state, "10-in cement plug; } .857 \\
\mathrm{ft} 3 \text { cement in hole. Welded } 14 \text { by } 12 \mathrm{ft} \text { to each } \\
133 / 8 \text {-ft casing. Cemented to } 1 \mathrm{ft} \text { bgs." While } \\
\text { such descriptions provide some detail, they are } \\
\text { unclear and do not address the deeper portions of } \\
\text { the holes/wells and whether they were filled with } \\
\text { drilling mud, infiltrating groundwater, or other } \\
\text { materials. }\end{array}$ & $\begin{array}{l}\text { Descriptions of well decommissioning are based on various } \\
\text { reports generated by contractors back in the early } 70 \text { 's and } \\
\text { information is often vague. We will clarify each well's } \\
\text { activities to the best extent possible. }\end{array}$ \\
\hline & $\begin{array}{l}\text { c) It appears the symbols for inches and feet } \\
\text { have been interchanged on some of the entries. } \\
\text { Many wells are noted as having a 10" cement } \\
\text { plug, please verify whether these are correct. } \\
\text { Others such as W-2 through W-19 are listed as } \\
\text { shallow wells (<10"). }\end{array}$ & Units of measure have been corrected. \\
\hline & $\begin{array}{l}\text { d) Wells GZ-1 and }-2 \text { are listed as having a } \\
\text { protective cover and lock. Is there a reason these } \\
\text { were not decommissioned and closed? }\end{array}$ & $\begin{array}{l}\text { No information is available as to why these two wells were } \\
\text { not decommissioned (perhaps they are the two wells that } \\
\text { DOE reconditioned but actually belong to the DoD). }\end{array}$ \\
\hline & $\begin{array}{l}\text { e) Wells EPA-1 and HTH-3 are listed as "not } \\
\text { found or casing was deteriorated beyond } \\
\text { plugging." Please clarify which is correct. }\end{array}$ & Well casings were deteriorated beyond plugging \\
\hline $\begin{array}{l}\text { 5. Table 1-3 } \\
\text { and Table 1-2 }\end{array}$ & $\begin{array}{l}\text { The well depths should be listed consistently } \\
\text { between the tables. Table } 1-2 \text { lists the W series } \\
\text { wells as }<10 \text { feet, however, Table } 1-3 \text { lists } \\
\text { specific depths for some of them and unknown } \\
\text { for others. }\end{array}$ & Data in both tables was combined. \\
\hline
\end{tabular}

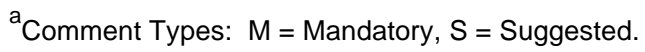

Return Document Review Sheets to NNSA/NSO Environmental Restoration Division, Attn: QAC, M/S 505.

LV9-19-06INDEP-ADEC comment responses 8-23 SN-014

Uncontrolled When Printed 


\section{NEVADA ENVIRONMENTAL RESTORATION PROJECT \\ DOCUMENT REVIEW SHEET}

Document Title/Number

Revision Number

Reviewer/Organization

\begin{tabular}{||l|l|l|l}
\hline 6. Table 1-3 & & $\begin{array}{l}\text { Based on Table 1-3, it appears prior hydrologic } \\
\text { monitoring program entailed collection } \\
\text { groundwater samples at depths ranging from 1 to } \\
140 \text { feet below ground surface. Please verify } \\
\text { whether this is the deepest groundwater } \\
\text { monitoring that was conducted, with the } \\
\text { exception of the drill-back work done shortly } \\
\text { after the testing. }\end{array}$ & $\begin{array}{l}\text { Based on available reports 140 feet was the deepest sampling } \\
\text { conducted under the LTHMP. }\end{array}$ \\
\hline
\end{tabular}




\section{NEVADA ENVIRONMENTAL RESTORATION PROJECT DOCUMENT REVIEW SHEET}

Document Title/Number

Revision Number

Reviewer/Organization

\begin{tabular}{|c|c|c|}
\hline $\begin{array}{l}\text { 7. Section } \\
1.3 .5, \text { p. } 25-26\end{array}$ & $\begin{array}{l}\text { The Desert Research Institute refined some of its } \\
2002 \text { modeling based on information complied } \\
\text { during the CRESP Independent Science } \\
\text { Assessment conducted during } 2004 \text {. The refined } \\
\text { model results are described in this section. } \\
\text { Unfortunately, we have not yet had a chance for } \\
\text { a third party modeler to review the report. Please } \\
\text { note, questions may arise on the modeling in the } \\
\text { future. Also, the second and third paragraphs on } \\
\text { page } 25 \text { state the } 2006 \text { modeling verified the } \\
2002 \text { modeling. Recommend the words "verify", } \\
\text { "verified", and "verifying" be replaced with } \\
\text { "refine", "update" or "support" (using correct } \\
\text { tense) instead. Verifying and validating typically } \\
\text { infer collecting groundwater data to demonstrate } \\
\text { actual measured parameters fall within the } \\
\text { modeled parameters. In this case deeper } \\
\text { groundwater has not been monitored. }\end{array}$ & $\begin{array}{l}\text { The } 2002 \text { modeling is not verified by the } 2006 \text { modeling, but } \\
\text { rather by the data collected by CRESP. Model verification } \\
\text { was one of the activities listed under the principles of the } \\
\text { Letter of Intent between DOE and the State of Alaska, } \\
\text { Department of Environmental Conservation. DOE's funding } \\
\text { for the CRESP assessment was with the explicit } \\
\text { understanding that a focus of the data collection was model } \\
\text { verification and reduction of risk uncertainty. } \\
\text { We agree that verifying and validating usually involve } \\
\text { comparing a model to data not used in the model } \\
\text { development. That is precisely what was done with the } \\
\text { Amchitka models. The independent data collected by CRESP } \\
\text { were used to evaluate model parameters with the finding that } \\
\text { the new measurements are within the ranges used in the } \\
\text { original model. In addition, the new data were used to tighten } \\
\text { the parameter ranges, thereby reducing uncertainty in the } \\
\text { model results. The data provided by CRESP extended very } \\
\text { deep into the subsurface, deeper than the groundwater } \\
\text { models. The magneto-telluric imaging provided salinity and } \\
\text { porosity profiles to depths of } 5 \text { km at each of the three test } \\
\text { sites. } \\
\text { For a detailed discussion of model validation, please see } \\
\text { Hassan, A. E., 2004. Validation of Numerical Ground Water } \\
\text { Models Used to Guide Decision Making, Ground Water, } \\
42(2), 277-290 \text {, and Hassan, A. E., 2004. A Methodology for } \\
\text { Validating Numerical Ground Water Models, Ground Water, } \\
42(3), 347-362 \text {. }\end{array}$ \\
\hline
\end{tabular}

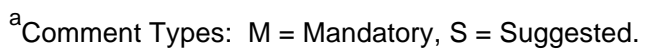

Return Document Review Sheets to NNSA/NSO Environmental Restoration Division, Attn: QAC, M/S 505 . 


\section{NEVADA ENVIRONMENTAL RESTORATION PROJECT \\ DOCUMENT REVIEW SHEET}

Document Title/Number

Revision Number

Reviewer/Organization

\begin{tabular}{|c|c|c|}
\hline 8. Figure $2-1$ & $\begin{array}{l}\text { It is unclear why "blocked pathways" and } \\
\text { "barrier" are depicted. These should be deleted } \\
\text { and the "potential pathways" depicted. } \\
\text { Footnotes or text in the document could be used } \\
\text { to further describe the fate and transport of } \\
\text { radionuclides originating from the source } \\
\text { areas/test cavities. }\end{array}$ & Conceptual Model being revised with better descriptions \\
\hline $\begin{array}{l}\text { 9. Section } \\
3.2, \\
\text { Institutional } \\
\text { Controls }\end{array}$ & $\begin{array}{l}\text { The second bullet item states that it is assumed } \\
\text { mineral rights have been withdrawn. This needs } \\
\text { to be verified with the USFWS. }\end{array}$ & $\begin{array}{l}\text { This has been verified with the USFWS. Change bullet to } \\
\text { read: } \\
\text { "The USFWS is the landowner, and maintains all mineral } \\
\text { rights for the island." }\end{array}$ \\
\hline $\begin{array}{l}\text { 10. Section } \\
3.2, \\
\text { Institutional } \\
\text { Controls }\end{array}$ & $\begin{array}{l}\text { I understand the Milrow plaque is missing and } \\
\text { needs to be replaced. This should be done as } \\
\text { part of the completion work unless there is an } \\
\text { agreement that the Office of Legacy } \\
\text { Management will do it. }\end{array}$ & $\begin{array}{l}\text { Added sentence: } \\
\text { "The Milrow event description plaque is missing but, the } \\
\text { restrictions plaque is still in tact." }\end{array}$ \\
\hline $\begin{array}{l}\text { 11. Section } \\
\text { 3.5, Public } \\
\text { Participation }\end{array}$ & $\begin{array}{l}\text { It should list "U.S. Fish and Wildlife Service, } \\
\text { Alaska Region" or "U.S. Fish and Wildlife } \\
\text { Service, Alaska Maritime Wildlife Refuge" and } \\
\text { "U.S. Army Corps of Engineers, Alaska } \\
\text { District". }\end{array}$ & Changes made to both. \\
\hline \multirow[t]{2}{*}{$\begin{array}{l}\text { 12. Appendix } \\
\text { A, Response } \\
\text { to Comments }\end{array}$} & $\begin{array}{l}\text { The following responses to prior DEC comments } \\
\text { have not been adequately addressed or warrant } \\
\text { further discussion: }\end{array}$ & \\
\hline & a) See comment \#1 above & Addressed above \\
\hline
\end{tabular}

${ }^{\mathrm{a} C o m m e n t}$ Types: $\mathrm{M}$ = Mandatory, $\mathrm{S}$ = Suggested.

Return Document Review Sheets to NNSA/NSO Environmental Restoration Division, Attn: QAC, M/S 505.

LV9-19-06INDEP-ADEC comment responses 8-23 SN-014

Uncontrolled When Printed 


\section{NEVADA ENVIRONMENTAL RESTORATION PROJECT \\ DOCUMENT REVIEW SHEET}

Document Title/Number

Revision Number

Reviewer/Organization

\begin{tabular}{||l|l|l||}
\hline & $\begin{array}{l}\text { b) Comment 8, first bullet item - the comment } \\
\text { states that test holes or wells remaining on the } \\
\text { island should be secured and information on } \\
\text { them provided to the landowner and LM. The } \\
\text { response states the comment was not } \\
\text { incorporated because it is not within the scope of } \\
\text { the document. This seems like a critical } \\
\text { component completion and transition into long } \\
\text { term surveillance and maintenance. }\end{array}$ & $\begin{array}{l}\text { Comment response was changed to read: "Added and } \\
\text { expanded tables 1-2 and 1-3 to address status of wells on the } \\
\text { Island" Also see response to comments 4b and c above. }\end{array}$ \\
\hline
\end{tabular}




\section{NEVADA ENVIRONMENTAL RESTORATION PROJECT \\ DOCUMENT REVIEW SHEET}

Document Title/Number

Revision Number

Reviewer/Organization

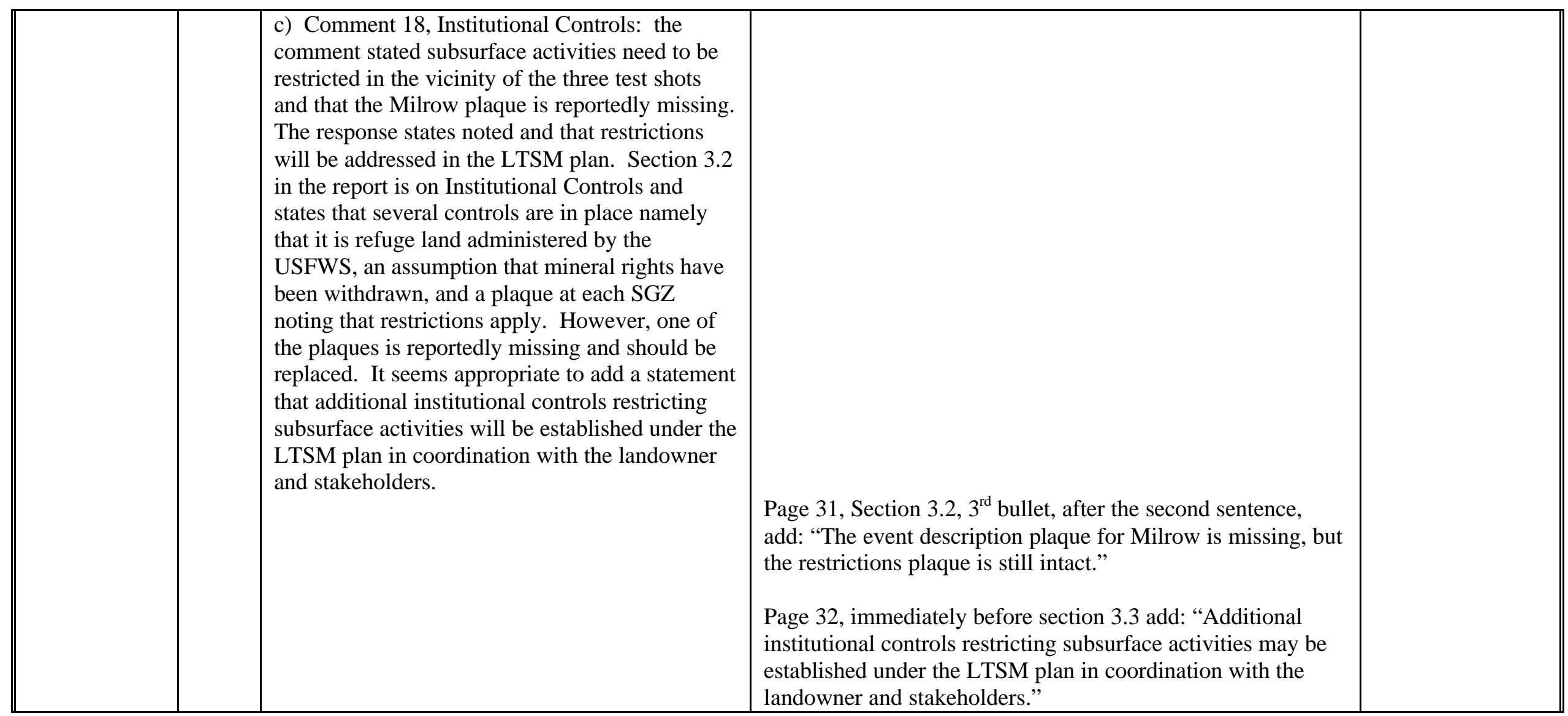

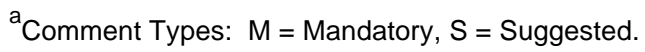

Return Document Review Sheets to NNSA/NSO Environmental Restoration Division, Attn: QAC, M/S 505.

LV9-19-06INDEP-ADEC comment responses 8-23 SN-014

Uncontrolled When Printed 


\section{Distribution}

\section{$\underline{\text { Copies }}$}

U.S. Department of Energy

1 (Uncontrolled)

National Nuclear Security Administration

Nevada Site Office

Technical Library

P.O. Box 98518, M/S 505

Las Vegas, NV 89193-8518

U.S. Department of Energy

1 (Uncontrolled, electronic copy)

Office of Scientific and Technical Information

P.O. Box 62

Oak Ridge, TN 37831-0062

Southern Nevada Public Reading Facility

2 (Uncontrolled, electronic copies)

c/o Nuclear Testing Archive

P.O. Box 98521, M/S 400

Las Vegas, NV 89193-8521

Manager, Northern Nevada FFACO

1 (Uncontrolled, electronic copy)

Public Reading Facility

c/o Nevada State Library \& Archives

100 N. Stewart Street

Carson City, NV 89701-4285

Aleutian/Pribilof Association, Inc.

2 (Uncontrolled, hard copies)

201 East 3rd Avenue

Anchorage, AK 99501-2455 